\title{
Article \\ Synthesis of Alkyne-Substituted Dihydropyrrolones as Bacterial Quorum-Sensing Inhibitors of Pseudomonas aeruginosa
}

\author{
Basmah Almohaywi $^{1}{ }^{(\mathbb{D}}$, Tsz Tin Yu ${ }^{2} * \mathbb{D}$, George Iskander ${ }^{2}$, Shekh Sabir ${ }^{2} \mathbb{D}$, Mohan Bhadbhade $^{3}$, \\ David StC. Black ${ }^{2}$ and Naresh Kumar ${ }^{2, *(D)}$ \\ 1 Department of Pharmaceutical Chemistry, College of Pharmacy, King Khalid University, \\ Abha 6142, Saudi Arabia; bal-mohawe@kku.edu.sa \\ 2 School of Chemistry, The University of New South Wales, Sydney, NSW 2052, Australia; \\ g.iskanderb@gmail.com (G.I.); s.sabir@student.unsw.edu.au (S.S.); d.black@unsw.edu.au (D.S.B.) \\ 3 Solid State and Elemental Analysis Unit, Mark Wainwright Analytical Centre, Division of Research, \\ The University of New South Wales, Sydney, NSW 2052, Australia; m.bhadbhade@unsw.edu.au \\ * Correspondence: tsztin.yu@unsw.edu.au (T.T.Y.); n.kumar@unsw.edu.au (N.K.)
}

check for

updates

Citation: Almohaywi, B.; Yu, T.T.; Iskander, G.; Sabir, S.; Bhadbhade, M.; Black, D.S.; Kumar, N. Synthesis of Alkyne-Substituted

Dihydropyrrolones as Bacterial Quorum-Sensing Inhibitors of Pseudomonas aeruginosa. Antibiotics 2022, 11, 151. https://doi.org/ 10.3390/antibiotics11020151

Academic Editor: Maria Fernanda N. N. Carvalho

Received: 30 December 2021

Accepted: 17 January 2022

Published: 25 January 2022

Publisher's Note: MDPI stays neutral with regard to jurisdictional claims in published maps and institutional affiliations.

Copyright: (C) 2022 by the authors. Licensee MDPI, Basel, Switzerland. This article is an open access article distributed under the terms and conditions of the Creative Commons Attribution (CC BY) license (https:// creativecommons.org/licenses/by/ $4.0 /)$.

\begin{abstract}
The Quorum-sensing system in Pseudomonas aeruginosa is responsible for the pathogenicity and the production of virulence factors and biofilm formation. Dihydropyrrolones were previously found to act as inhibitors of QS-dependent bacterial phenotypes. In this study, a range of dihydropyrrolone (DHP) analogues was synthesized via the lactone-lactam conversion of lactone intermediates followed by the formation of novel acetylene analogues of dihydropyrrolones from brominated dihydropyrrolones via Sonogashira coupling reactions in moderate to high yields. Upon biological testing, the most potent compounds, $\mathbf{3 9 - 4 0}$ and $\mathbf{4 4}$, showed higher bacterial quorum-sensing inhibitory (QSI) activity against $P$. aeruginosa reporter strain at $62.5 \mu \mathrm{M}$. Structure-activity relationship studies revealed that di-alkynyl substituent at the exocyclic position of DHPs possessed higher QSI activities than those of mono-alkynyl DHPs. Moreover, a hexyl-substituent at C3 of DHPs was beneficial to QSI activity while a phenyl substituent at C4 of DHPs was detrimental to QSI activity of analogues.
\end{abstract}

Keywords: quorum sensing; alkyne synthesis; Pseudomonas aeruginosa; dihydropyrrolones

\section{Introduction}

Pseudomonas aeruginosa regulates its pathogenicity through an intercellular densitydependent communication system mediated by the binding of signaling molecules to quorum-sensing (QS) receptors such as LasR, which, upon its activation, modulates the expression of multiple genes responsible for the production of various virulence factors (e.g., pyocyanin, rhamnolipids, and pyoverdine), biofilm formation, the swarming motility, and antibiotic resistance. While conventional antibiotics exert increased selective pressure on bacteria, resulting in the development of antibiotic resistance [1-3], inhibition of quorum sensing interrupts the cell-to-cell coordination without exerting a selective pressure on bacteria. This may reduce the chance of bacterial resistance. Therefore, antagonists of LasR are considered an effective alternative strategy with a novel mode of actions for the treatment of infections while preventing bacterial resistance [1].

Fimbrolides, or halogenated furanones such as 5-dibrominated furanones $\mathbf{1}$ and $\mathbf{2}$ (Figure 1), were first synthesized in 1997 by Manny et al. [4] and are known to possess antimicrobial and quorum-sensing inhibitory (QSI) activities [5-7]. They were previously found to act as QS inhibitors of AHL that mediate QS phenotypes [5,6]. We previously reported the design, synthesis, and evaluation of fimbrolide-nitric oxide donor hybrids as antimicrobial agents [7]. However, their therapeutic use is limited by their instability, ease of hydrolysis, and toxicity [8]. Nevertheless, fimbrolides or 5-dibrominated furnaones can 
be utilized as a starting template for chemical manipulation into 1,5-dihydropyrrol-2-ones (DHPs) such as compound 3 . The dihydropyrrole-2-one moiety is present in several classes of biologically important natural and synthetic molecules such as rolipram, pulchellalactam [9], and Jatropham [10]. The 1,5-dihydropyrrol-2-one is an isosteric five-membered ring that is structurally related to furanones but contains a cyclic amide bond in substituting the hydrolytically and enzymatically labile cyclic ester in the natural and synthetic furanones. The lactam ring is hydrolytically more stable, which reduces the susceptibility of the ring-opening reaction by either enzymatically or chemical lactonolysis. [11,12] Several DHPs were found to possess antimicrobial activity, QS, and biofilm inhibitory activities [13] such as those reported by our group [14-16], including DHPs with a thioether [17] or a seleno-urea [18] moiety. In addition, the biological activities of DHP-related compounds were also studied by other research groups [19-22], including rubrolide derivatives, which showed antibacterial [23], anticancer [24], and herbicidal [25] activities. Moreover, a recent paper by Ma et al. also reported the synthesis and anti-virulence activities of several furanones and aryl-substituted pyrrolidone derivatives as quorum sensing inhibitors [26].<smiles>O=C1C=C(Br)C(=CBr)O1</smiles>

1<smiles>[R]C(CCC)C1=C/C(=C/Br)OC1=O</smiles>

2<smiles>CCCC(Br)C1=CC(=C(Br)Br)N(c2ccccc2)C1=O</smiles>

3

$\mathrm{R}=\mathrm{H}, \mathrm{Br}, \mathrm{OAC}$

Figure 1. Furanones and DHP examples.

The acetylene functionality is frequently found in many synthetic products as well as natural products that can be isolated from a wide range of plant species, fungal and bacterial cultures, and marine sponges and corals [27-29]. Acetylene groups are commonly used in medicinal chemistry for their electronic effects, equivalent to aromatic rings and providing structural rigidity (Figure 2) [30]. They are present in some of the sedativehypnotic drugs such as meparfynol 4, ethinamate, and the antiparkinsonian rasagiline 5 [30]. They are also present in the synthetic retinoid tazarotene 6 , which is used for the treatment of acne, psoriasis, and photo-aging, as well as the antiviral compound efavirenz 7 , the orally active contraceptives ethynyl-estradiol, norethindrone, and the implantable contraceptive etonogestrel [30]. Acetylene is also found in the natural pesticide falcarinol, the nervous system toxin oenanthotoxin, and the furanone-containing natural product cleviolide 8. [31].

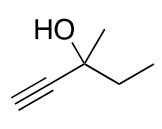

4

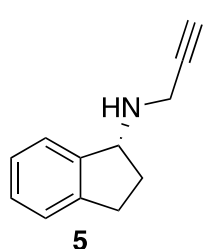

5<smiles>CCOC(=O)c1ccc(C#Cc2ccc3c(c2)C(C)(C)CCS3)nc1</smiles><smiles>O=C1Nc2ccc(Cl)cc2C(C#CC(F)(F)F)(C(F)(F)F)O1</smiles><smiles>CC(C)=CC#CC1=CC(=O)OC1</smiles><smiles>CN(C/C=C/C#CC(C)(C)C)Cc1cccc2ccccc12</smiles>

9

Figure 2. Examples of acetylene in pharmaceuticals. 
The installation of acetylene moieties into molecules can be achieved via the Sonogashira cross-coupling reaction between an organohalide and a terminal alkyne. The Sonogashira reaction was first reported in 1975 by Kenkichi Sonogashira and his co-workers. Since then, it has been one of the most important and commonly used cross-coupling reactions for forming carbon-carbon bonds. It is sometimes considered as important as the Suzuki-Miyaura reaction for the synthesis of compounds that are useful for medicinal chemistry research [32]. The Sonogashira cross-coupling reaction was featured in the synthesis of acetylenic derivatives of furanones [31,33] and quinolines with potential antimicrobial activity [34], as well as 2-aminoimidazole with antibiofilm activity [35]. It was also employed in the total synthesis of enediyne-containing antibiotics such as calicheamicin and dynemicin [36]. Many pharmaceutically important molecules were synthesized via the Sonogashira reaction, including terbinafine 9 (lamisil), which is used to treat fungal infections, and the aforementioned tazarotene $\mathbf{6}$.

Recently, our group reported the synthesis of acetylene-containing furanones 10-12, which possessed low to moderate quorum-sensing inhibitory (QSI) activity, from brominated furanones 1 via Sonogashira cross-coupling reaction (Figure 3) [37]. In addition, we developed a method to convert brominated furanones into DHPs using a ring-opening/ringclosing lactamization reaction with amine nucleophiles [38]. We also reported the structural activity relationships (SAR) of our DHPs-based AHL mimics [15]. Dihydropyrrolones (DHPs) 13a-c that were synthesized from their corresponding furanones using the ringopening/ring-closing lactamisation reaction demonstrated good QSI and antibiofilm activities against $P$. aeruginosa [15] and E. coli [16] with minimal effect on bacterial growth $[15,16]$. Furthermore, our work on the synthesis of a series of thioether containing DHP analogues as PqsR antagonist and novel seleno- and thio-urea containing dihydropyrrol-2-one (DHP) analogues as LasR antagonists [18] was also reported. Prompted by these previous findings $[14,15,18,37]$ and the possibility of exploiting the brominated exocyclic alkene at the 5-position of DHP, herein we aimed to introduce acetylene group(s) at the 5-position of the DHP and investigate their effect on the biological activity.

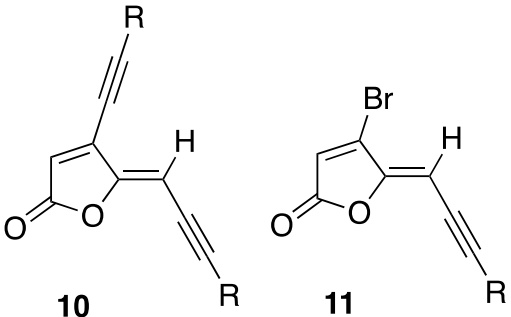

10

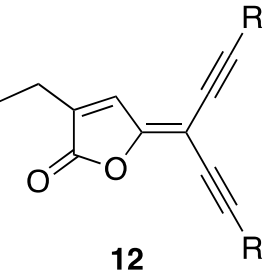

12<smiles>[R]C=C1C(c2ccccc2)=CC(=O)N1[R7]</smiles>

13a: $R=4-B r, R^{1}=H, R^{2}=H$

13b: $R=H, R^{1}=B r, R^{2}=H$

13c: $R=H, R^{1}=H, R^{2}=n-b u t y l$

Figure 3. Acetylene-containing furanones based on our recent work.

\section{Results and Discussion}

\subsection{Synthesis}

In this study, we investigated the introduction of acetylene substituents via the Sonogashira cross-coupling reaction of brominated DHPs to give acetylene-substituted DHPs. The reaction typically involves the use of a palladium catalyst and copper as a co-catalyst to form a carbon-carbon bond between a terminal alkyne, which serves as the coupling partner, and an aryl or vinyl halide [32,39].

The synthesis of acetylene substituted DHPs was initially attempted by the lactamisation of the previously reported Sonogashira furanone products [37] with aqueous ammonia and/or alkylamine (e.g., propylamine) at room temperature and monitored by TLC. However, this synthetic strategy was proven to be unsuccessful. This could be attributed to the reduced reactivity of the acetylene-containing furanones towards lactamisation. Therefore, an alternative synthetic pathway for the synthesis of compounds 18-20 was sought. This 
alternative pathway involved the lactamisation of the brominated furanones $\mathbf{1 4 - 1 5}$ prior to the Sonogashira reaction. The lactamisation reaction of brominated furanones 14 and 15 using ammonia gas successfully afforded brominated DHPs 16 and 17. The Sonogashira reaction was then carried out between the brominated DHPs 16-17 and phenylacetylene or 4-methylphenylacetylene (2.5 eq.) with the presence of $\mathrm{CuI}(0.1$ eq.), bistriphenylphosphine)palladium(II) dichloride $\left(\mathrm{PdCl}_{2}\left(\mathrm{PPh}_{3}\right)_{2}\right.$ (0.1 eq.), and triethylamine (TEA, 1 eq.) in degassed THF under reflux conditions to give the di-alkynylated NH DHPs 18-20 in $62-72 \%$ yields as reported in our recently published conference paper (Scheme 1) [40]. During the optimization of rection process, it was found that heating was crucial for the success of the reaction and could minimize the formation of the acetylene homo-adduct. Moreover, it was found that the use of triethylamine as the solvent and the base could also result in the formation of the Sonogashira products, although the use of THF as the solvent in this reaction afforded the Sonogashira products in the highest yield [40].

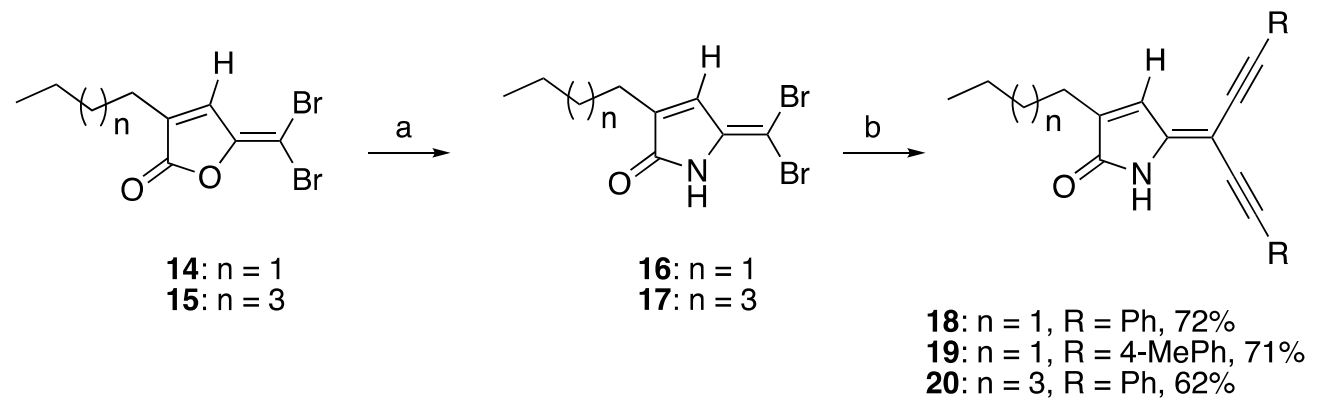

Scheme 1. Lactamisation of furanone and Sonogashira coupling reaction of compounds 18-20. Reaction conditions: (a) ammonia gas, DCM, r.t.; (b) $\mathrm{PdCl}_{2}\left(\mathrm{PPh}_{3}\right)_{2} \mathrm{CuI}$, TEA, terminal alkyne, THF, reflux [40].

Recently, we reported the QS inhibitory activities of 5-methylene-4-phenyl-1,5-dihydro2H-pyrrol-2-ones such as compounds 21-23, which can be synthesized via the lactonelactam conversion method $[15,41]$. The synthesis began with the acid-catalyzed condensation of phenylacetones with glyoxylic acid, producing 5-hydroxyfuranones. In the key lactone-lactam conversion step, furanones were treated with thionyl chloride followed by aqueous ammonia to provide the intermediate 5-hydroxylactams, which were subsequently subjected to radical bromination with $N$-bromosuccinimide (NBS) to give 5-bromo-methylene-5-hydroxylactams, followed by dehydration to obtain the target compounds 21-23.

To investigate the effect of introduction of a bulky mono-substituted acetylene group to the exocyclic vinylic alkene of compounds 21-23 while keeping the phenyl moiety on C4 on the QS activity of the compounds, 5-(bromomethylene) DHPs 21-23 were subjected to the Sonogashira coupling reaction with phenylacetylene, $\mathrm{CuI}$, and palladium catalyst to generate compounds 24-26 in 35-90\% yield (Scheme 2). While compounds 24 and 25 were synthesized in good yields of $90 \%$ and $75 \%$, respectively, the low yield of compound 26 could be due to its poor solubility in organic solvent and high adsorption on silica gel, leading to considerable loss of the compound upon purification.

To study the effect of introducing alkyl groups at the ring nitrogen, the synthesis of compounds 36-44 was investigated (Scheme 3). The precursor furanones 14-15 and 27-29 were synthesized following our previously reported procedure using sulfuric acidcatalyzed cyclization of brominated 2-alkyl-levulinic acids [4,7,42]. 
<smiles>[R]c1ccc(C2=CC(=O)NC2=CC)cc1</smiles>

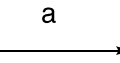

21: $\mathrm{R}=\mathrm{H}$

22: $R=2-F$

23: $\mathrm{R}=4-\mathrm{Br}$

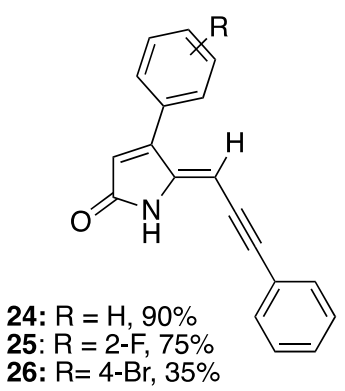

26: $R=4-B r, 35 \%$

Scheme 2. Sonogashira synthesis of 4-phenyl DHP derivatives. Reaction conditions: (a) $\mathrm{PdCl}_{2}\left(\mathrm{PPh}_{3}\right)_{2}$, CuI, TEA, argon, alkyne, THF, and reflux.
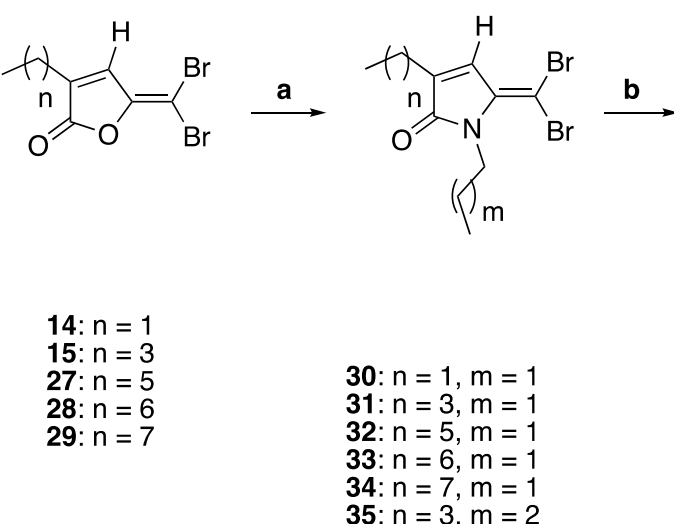

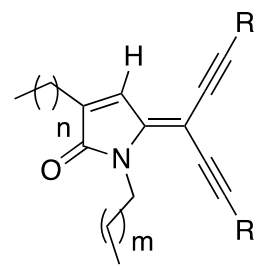

36: $\mathrm{n}=1, \mathrm{~m}=1, \mathrm{R}=\mathrm{Ph}, 37 \%$

37: $n=1, m=1, R=4-M e P h, 38 \%$

38: $n=3, m=1, R=P h, 48 \%$

39: $n=3, m=1, R=4-M e P h, 15 \%$

40: $\mathrm{n}=5, \mathrm{~m}=1, \mathrm{R}=\mathrm{Ph}, 39 \%$

41: $\mathrm{n}=6, \mathrm{~m}=1, \mathrm{R}=\mathrm{Ph}, 96 \%$

42: $\mathrm{n}=7, \mathrm{~m}=1, \mathrm{R}=\mathrm{Ph}, 30 \%$

43: $\mathrm{n}=3, \mathrm{~m}=2, \mathrm{R}=\mathrm{Ph}, 78 \%$

44: $n=3, m=1, R=H, 31 \%$ (over two steps)

Scheme 3. DHP analogues containing diacetylene groups and substituents at the ring nitrogen. Reaction conditions: (a) propylamine or butylamine, DCM, r.t., and 3 h; (b) $\mathrm{PdCl}_{2}\left(\mathrm{PPh}_{3}\right)_{2}, \mathrm{CuI}$, TEA, argon, alkyne, THF, and reflux.

Following the synthesis of the precursor furanones 14-15 and 27-29, the N-propyl analogues 30-34 were obtained in 30-96\% yields by lactamization using excess equivalent of propylamine in dichloromethane, while the synthesis of $\mathbf{3 5}$ was synthesized using the same synthetic procedure for compounds 30-34 but with butylamine instead of propylamine [43]. The 5-dibromo DHPs 30 and 31 were reacted with phenylacetylene to give compounds 36 and 38 in 37\% and 48\% yield. Alternatively, the 5-dibromo DHPs 30 and 31 were also reacted with $p$-tolylacetylene to give alkyne compounds 37 and 39 in moderate to low yields of $37 \%$ and $15 \%$, respectively. The longer chain 5-dibromo DHPs $40-43$ were also synthesized from their corresponding 5-dibromo DHPs 30-35 in the analogous reactions in $30-96 \%$ yields. Finally, compound 44 with a terminal acetylene group was synthesized over two steps, by firstly reacting compound 31 with trimethylsilyl-protected acetylene followed by the deprotection of the trimethylsilyl protecting group to yield the terminal acetylene group.

The structures of the Sonogashira products 18-20, 24-26, and 36-44 were confirmed by spectroscopic analysis including ${ }^{1} \mathrm{H} \mathrm{NMR},{ }^{13} \mathrm{C} \mathrm{NMR}$, and mass spectrometry (see Supplementary Materials File S1). In the acetylene products, the C4 hydrogen resonance of 18-20 and 36-44 was observed to shift downfield in the Sonogashira coupling products at 7.13-7.26 ppm compared to $7.02 \mathrm{ppm}$ in the DHP intermediates. The additional phenyl ring proton resonances for compounds 18-20 and 36-44 were observed at 7.20-7.60 ppm in the aromatic region of the ${ }^{1} \mathrm{H}$ NMR spectra. Meanwhile, the newly formed acetylene carbons were confirmed by ${ }^{13} \mathrm{C}$ NMR and were observed at 83.0-98.0 ppm. The number of aliphatic carbons was also confirmed by ${ }^{13} \mathrm{C}$ NMR for compounds 18-20 and 36-44 
as these carbons resonated in the aliphatic region between 22.0 and $40.0 \mathrm{ppm}$. The $\mathrm{CH}_{2}$ adjacent to the ring nitrogen was observed at 30.0-40.0 ppm in the ${ }^{13} \mathrm{C}$ NMR spectrum. The exocyclic singlet protons $(\mathrm{C}=\mathrm{CHBr})$ adjacent to the newly formed acetylene phenyl of the Sonogashira products 24-26 were observed upfield at 5.47-5.59 ppm compared to 6.16-6.35 ppm in the DHP intermediates 21-23.

\subsection{X-ray Analysis of Sonogashira DHP Compounds}

To confirm the structures of the acetylene compounds 18 (C3-butyl, C4-H) and 26 (C4-(p-Br-phenyl), these compounds were crystallized from acetonitrile to give yellow needles and yellow plate-shaped crystals, respectively, that were suitable for single crystal X-ray diffraction. The ORTEP views of molecules 18 and 26 along with the labelling of atoms are presented in Figure 4a,b.

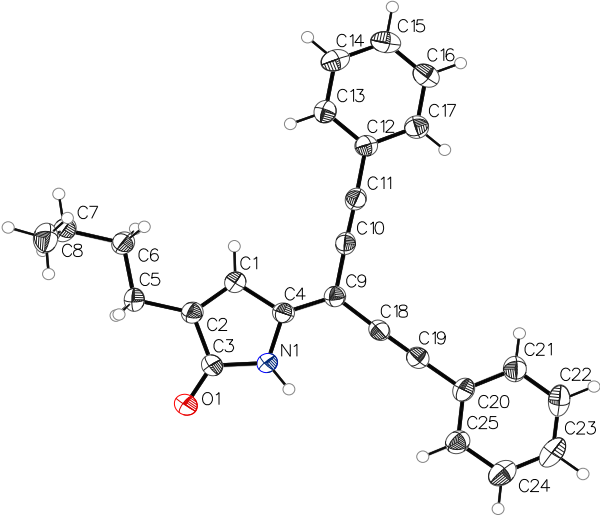

(a)

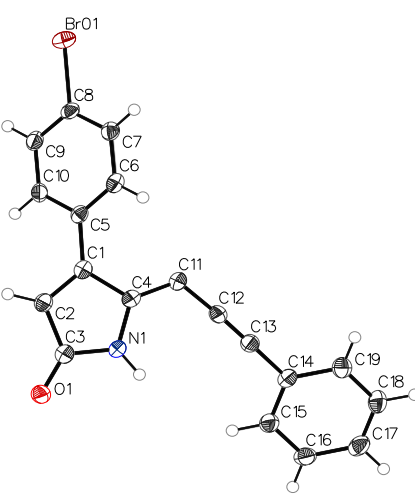

(b)

Figure 4. ORTEP representation of compounds 18 (a) and $26(\mathbf{b})$.

Compound 18 with a butyl group at C3 is essentially planar, whereas molecule $\mathbf{2 6}$ with a $p$-bromophenyl group at C4 is not planar. In 26, the phenyl ring C5-C10 is rotated about the $\mathrm{C} 1-\mathrm{C} 5$ bond by $-54.3^{\circ}$, presumably to avoid the short $\mathrm{H}$... H contact of the hydrogens from carbon atoms C6 and C11. Both 18 (Figure 5a) and 26 (Figure 5b) self-associate in a very similar fashion via $\mathrm{N}$... O hydrogen bonds. An additional C-H ... O interaction ("hydrogen bond") was also observed in $\mathbf{1 8 .}$

\subsection{QS Inhibition}

QS inhibition assay was performed on the synthesized acetylene DHPs to evaluate their efficacy and to study their structure-activity relationship (SAR). These compounds were tested against $P$. aeruginosa $\mathrm{MH602,} \mathrm{a} \mathrm{reporter} \mathrm{strain} \mathrm{that} \mathrm{measures} \mathrm{the} \mathrm{level} \mathrm{of} \mathrm{green}$ fluorescent protein (GFP), following the method reported by Hentzer et al. [5] An inhibitor is expected to reduce the expression and the production of GFP. In this study, the liquid cultures of the P. aeruginosa reporter strain MH602 were incubated in various concentrations $(250,125$, and $62.5 \mu \mathrm{M})$ of the synthesized compounds and the fluorescence of GFP at $\lambda=535 \mathrm{~nm}$ was recorded. A fimbrolide, furanone $30(\mathbf{1})$, was used as a positive control to validate the assay protocol. The optical density (OD) at $600 \mathrm{~nm}$ was also measured to determine the potential effect of the tested compounds on bacterial growth to ensure that their QSI activity was not due to bactericidal effects.

The results for the tested compounds are presented in Table 1. The percentage QS inhibition of the compounds was calculated as the percentage difference of GFP intensity between the sample and the control at the same time point when the fluorescence reached its maximum value in the control. The acetylene compounds reduced QS by $43-80 \%$ at $250 \mu \mathrm{M}$, $28-66 \%$ at $125 \mu \mathrm{M}$, and $24-56 \%$ at $62.5 \mu \mathrm{M}$. Moreover, most of the alkyne derivatives did not have a substantial effect on the viability of bacterial cells. 
(a)

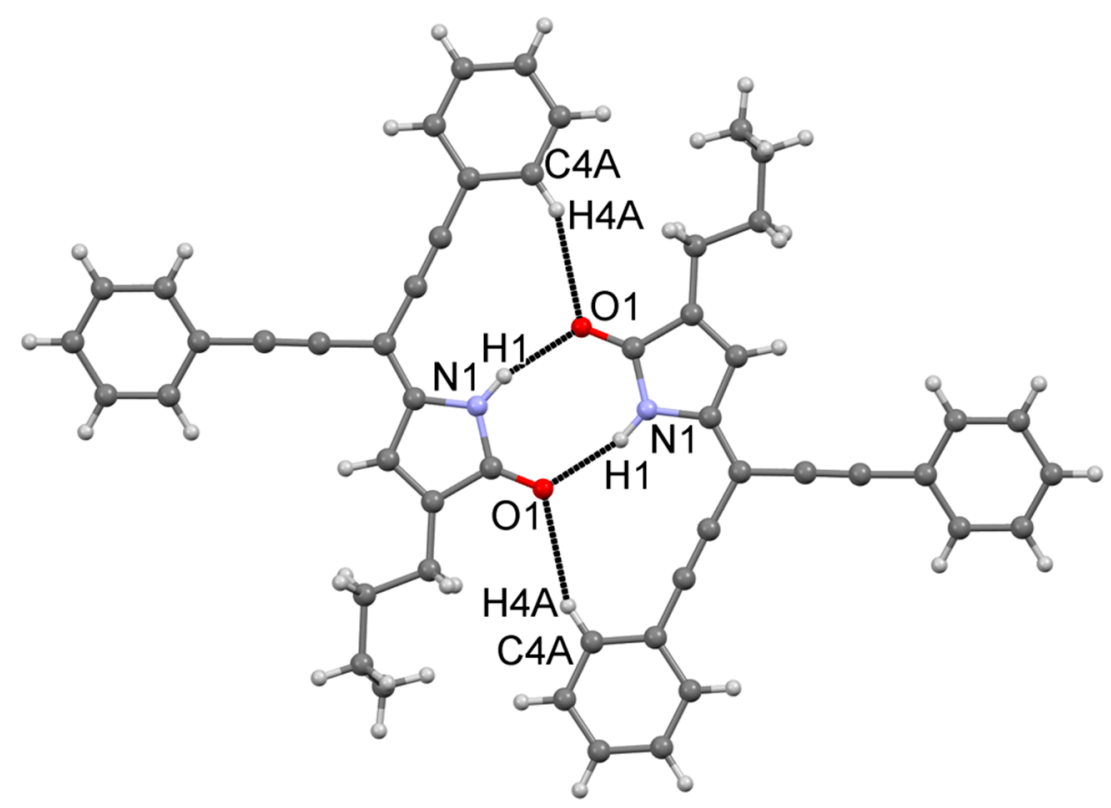

(b)

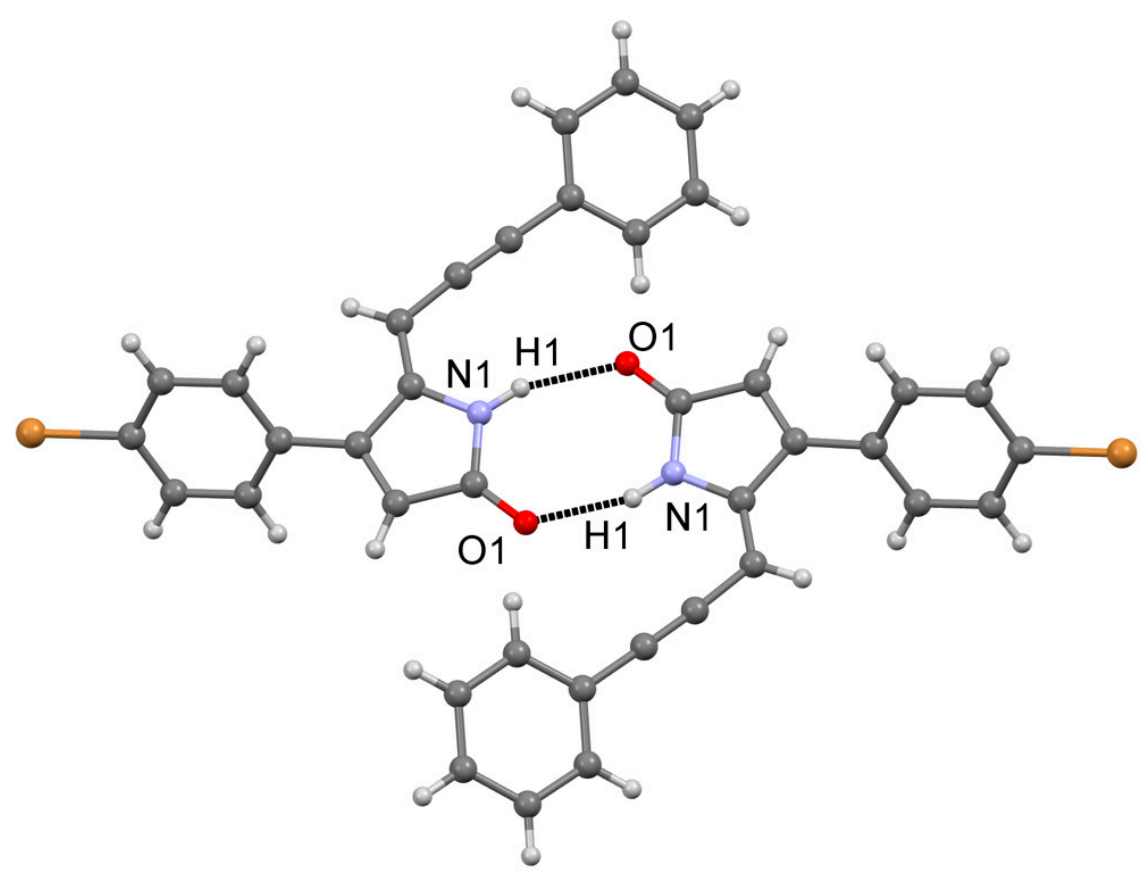

Figure 5. Dimeric association via H-bonding interactions in structures of compounds 18 (a) and (b) 26 .

Among the di-alkynyl DHPs 18-20 with a C3 alkyl group but no substituent at N1position, molecules 18 and 20 bearing a terminal phenyl ring possessed higher QS inhibition at $62.5 \mu \mathrm{M}$ (QSI $=47.8 \%$ and $39.3 \%$, respectively) than compound 19 bearing a p-methylphenyl group (QSI $=24.1 \%$ ). Interestingly, while the installation of the phenylacetylene groups generally increased the QSI activities of the analogues, the introduction of a methyl-substituent at the terminal phenyl rings decreased the QSI activity significantly. DHP 19 with a methyl-substituent at the terminal phenyl rings had a significantly lower QSI activity of $24.1 \%$ when compared to its parent compounds 18 (QSI $=47.8 \%$ ) with 
unsubstituted terminal phenyl rings and $16(\mathrm{QSI}=44.7 \%)$ without the phenylacetylene moiety at $62.5 \mu \mathrm{M}$.

Table 1. Percentage QS inhibition of the tested compounds against P. aeruginosa reporter strain MH602.

\begin{tabular}{|c|c|c|c|}
\hline \multirow{2}{*}{ Compound } & \multicolumn{3}{|c|}{ Concentration $(\mu \mathrm{M})$} \\
\hline & 250 & 125 & 62.5 \\
\hline 16 & $\mathrm{~b}^{2} 58.6 \pm 2.1$ & a $47.5 \pm 6.5$ & a $44.7 \pm 4.6$ \\
\hline 17 & b $46.4 \pm 1.1$ & a $32.9 \pm 1.4$ & a $19.5 \pm 1.9$ \\
\hline 18 & a $52.2 \pm 8.7$ & a $51.0 \pm 1.8$ & a $47.8 \pm 0.8$ \\
\hline 19 & a $43.9 \pm 2.9$ & a $25.0 \pm 2.7$ & a $24.1 \pm 9.3$ \\
\hline 20 & a $59.2 \pm 0.4$ & a $44.8 \pm 3.4$ & a $39.3 \pm 3.6$ \\
\hline 24 & a $49.2 \pm 3.8$ & a $35.2 \pm 4.5$ & a $28.5 \pm 0.7$ \\
\hline 25 & a $46.6 \pm 4.8$ & a $30.7 \pm 4.5$ & a $20.0 \pm 7.2$ \\
\hline 26 & a $54.8 \pm 5.6$ & a $39.7 \pm 1.5$ & a $30.2 \pm 6.7$ \\
\hline 36 & b $70.0 \pm 3.6$ & a $55.2 \pm 1.1$ & a $36.4 \pm 8.3$ \\
\hline 37 & a $45.4 \pm 1.3$ & a $28.0 \pm 1.5$ & a $25.1 \pm 2.8$ \\
\hline 38 & a $67.6 \pm 0.6$ & $57.8 \pm 5.9$ & a $40.6 \pm 3.3$ \\
\hline 39 & b $65.8 \pm 4.6$ & a $63.0 \pm 4.5$ & a $54.1 \pm 4.4$ \\
\hline 40 & b $71.2 \pm 8.1$ & a $65.3 \pm 1.6$ & a $52.9 \pm 6.7$ \\
\hline 41 & b $68.6 \pm 3.1$ & a $53.3 \pm 8.1$ & a $43.3 \pm 6.1$ \\
\hline 42 & a $66.1 \pm 6.4$ & a $54.8 \pm 6.2$ & a $39.9 \pm 8.9$ \\
\hline 43 & a $59.5 \pm 0.3$ & a $48.7 \pm 3.2$ & a $24.3 \pm 1.9$ \\
\hline 44 & b $79.8 \pm 0.8$ & a $66.1 \pm 6.2$ & a $55.8 \pm 4.6$ \\
\hline $\mathbf{d}_{1}$ & c $84.8 \pm 2.9$ & c $82.5 \pm 2.5$ & c $74.4 \pm 3.6$ \\
\hline
\end{tabular}

a Bacterial growth inhibition $\leq 15 \%{ }^{\text {b }}$ growth inhibition between 15 and $30 \%{ }^{c}$ growth inhibition greater than $30 \%{ }^{\mathrm{d}}$ positive control; \pm the standard deviation of the mean for at least three independent experiments. In each independent experiment, compounds were tested in triplicate.

On the other hand, the $\mathrm{N}$-unsubstituted 4-aryl DHPs 24 (C4-phenyl), 25 (C4-2-fluorophenyl), and 26 (C4-4-bromophenyl) with a single acetylene unit at the exocyclic position showed lower QS inhibition compared to their parent molecules 21-23 without the acetylene substituents [15]. The observed reduction in QS activity could be attributed to the bulky phenyl and acetylene groups, which hinder the molecules from binding to the bacterial receptor protein. This observation is consistent with lower activities of the mono- and di-substituted acetylene-derived furanones reported by Biswas et al. [37].

Among the di-alkynyl DHPs bearing aliphatic chains at both C3 and N1, compound 44 with unsubstituted terminal acetylene moieties possessed the highest QSI activities at all tested concentrations. The introduction of a terminal phenyl ring was detrimental to QSI activity as the corresponding compound $\mathbf{3 8}$ with a terminal phenyl ring at the acetylene moieties showed a lower QSI of $40.6 \%$ compared to compound 44 with a QSI of $55.8 \%$ at $62.5 \mu \mathrm{M}$. Interestingly, the effect of the introduction of an alkyl group at N1-position of the DHP on the QSI activity of the analogues depends on the substituent at the terminal phenyl rings of the acetylene moieties. For compounds with a phenylacetylene moiety, the introduction of a methyl-substituent at N1 position decreased the QSI activity slightly as $\mathrm{N}$-methyl-substituted compound 38 possessed a lower QSI of $40.6 \%$ compared to its corresponding unsubstituted compound $18(\mathrm{QSI}=47.8 \%)$ at $62.5 \mu \mathrm{M}$. In contrast, the introduction of a methyl-substituent at N1 position of DHP bearing a $p$-methylphenylacetylene moiety enhanced the QSI activity of the analogue significantly as $N$-methyl-substituted compound 39 possessed a higher QSI of $54.1 \%$ compared to its corresponding unsubstituted compound $19(\mathrm{QSI}=24.1 \%)$ at $62.5 \mu \mathrm{M}$. In addition, lengthening the $N$-methyl-substituent to $N$-ethyl-substituent was found to be detrimental to QSI activity as $\mathrm{N}$-ethyl-substituted compound 43 exhibited a lower QSI of $24.3 \%$ compared to the corresponding $N$-methylsubstituted compound 38, which exhibited a QSI of $40.6 \%$ at $62.5 \mu \mathrm{M}$. Moreover, compounds with different aliphatic chain length at $\mathrm{C} 3$ were also synthesized to investigate the optimum chain length for the highest QSI activity. It was found that a hexyl-substituent at C3 was optimum for QSI activity, in which compound $\mathbf{4 0}$ with a hexyl-substituent at C3 possessed 
the highest QSI of $52.9 \%$ at $62.5 \mu \mathrm{M}$ among this series of compounds. Compounds with a longer or shorter alkyl chain length generally showed lower QSI activities.

\section{Experimental}

\subsection{Quorum-Sensing Inhibition Assay for PAMH602}

The P. aeruginosa MH602 PlasB::gfp (ASV) reporter strain was used. An overnight culture was prepared in Luria-Bertani (LB10) media supplemented with gentamycin $(40 \mu \mathrm{M})$. This bacterial culture solution was diluted (1 in 100) with LB10 supplemented with gentamycin $(15 \mu \mathrm{M})$. Stock solutions of the synthesized compounds were prepared at $20 \mathrm{mM}$ in DMSO. Compounds were pipetted into each well with final concentrations of 250, 125, and $62.5 \mu \mathrm{M}$ (in triplicate) with a final volume of $200 \mu \mathrm{L}$ with the prepared bacterial culture. The negative control was prepared containing $200 \mu \mathrm{L}$ of the bacterial culture without the tested compounds. The plates were incubated at $37^{\circ} \mathrm{C}$ for $15 \mathrm{~h}$. The plates were measured for GFP expression (fluorescence: excitation $485 \mathrm{~nm}$, emission $535 \mathrm{~nm}$ ) using a microplate reader (Wallac Victor, Perkin-Elmer, Minneapolis-Saint Paul, MN, USA), and the cell growth was also assessed by recording the OD at $600 \mathrm{~nm}$.

\subsection{Methodology for X-ray Crystallography}

A suitable single crystal of $\mathbf{1 8}$ (CCDC 2131315) and 26 (CCDC 2131273) obtained from the recrystallisation of the corresponding compound from acetonitrile was selected under a polarizing microscope (Leica M165Z) mounted on a MicroMount (MiTeGen, Ithaca, NY, USA) consisting of a thin polymer tip with a wicking aperture. The X-ray diffraction measurements were carried out on a Bruker D8 Quest Single Crystal diffractometer with Photon II detector at $150 \mathrm{~K}$ by using I $\mu$ S 3.0 Microfocus Source with Mo-K $\alpha$ radiation $(\lambda=0.710723 \AA)$. The single crystal, mounted on the goniometer using cryo loops for intensity measurements, was coated with paraffin oil and then quickly transferred to the cold stream using an Oxford Cryo stream 800 attachment. Symmetry-related absorption corrections using the program SADABS were applied and the data were corrected for Lorentz and polarization effects using Bruker APEX3 software [44]. The structure was solved by ShelxT (intrinsic phasing) [45] and the full-matrix least-square refinement was carried out using Shelxl [46] in Olex2 [47]. The non-hydrogen atoms were refined anisotropically. The molecular graphic was generated using program Olex2 [47] (Supplementary Materials Tables S3 and S4).

Crystal data: compound $18 \mathrm{C}_{25} \mathrm{H}_{21} \mathrm{NO}$ (Table S1), M.W. = 351.4490, Monoclinic. Cell dimensions: $\mathrm{a}=8.8068$ (7) $\AA, \mathrm{b}=20.8376$ (15) $\AA, \mathrm{c}=10.6832$ (6), and beta = 104.884 (2) $\AA$; compound $26 \mathrm{C}_{19} \mathrm{H}_{12}$ BrNO (Table S2), M.W. = 350.2150, Monoclinic, Cell dimensions: $\mathrm{a}=11.944$ (4) $\AA, \mathrm{b}=9.578$ (3) $\AA, \mathrm{c}=13.798$ (4), and beta $=105.385$ (6) $\AA$. Crystallographic data have been deposited with the Cambridge Crystallographic Data Centre with publication numbers CCDC 2131315 and CCDC 2131273. A copy of the data can be obtained free of charge from CCDC, 12 Union Road, Cambridge, CB2 1EZ, UK, or by e-mail: deposit@ccdc.cam.ac.uk.

\subsection{Synthesis Procedures \\ 3.3.1. General Information}

Commercially available reagents were purchased from standard suppliers such as Sigma Aldrich, Alfa Aesar, Combi-Blocks, and Oakwood Chemicals. The synthetic procedures have been reported for all compounds as general methods and appropriate references have been given for known compounds. Melting points were measured using an OptiMelt melting point apparatus and are reported without correction. High-resolution mass spectra were recorded by the Bioanalytical Mass Spectrometry Facility, UNSW, on an Orbitrap LTQ $\mathrm{XL}$ ion trap mass spectrometer using a nanospray (nano-electrospray) ionization source under positive ESI mode. The ${ }^{1} \mathrm{H}$ and ${ }^{13} \mathrm{C}$ NMR spectra were determined in the designated solvent on a Bruker DPX 300 spectrometer or a Bruker Avance 400 spectrometer. Chemical shifts $(\delta)$ are quoted in parts per million (ppm) internally referenced relative to the solvent 
nuclei. Multiplicities in ${ }^{1} \mathrm{H}$ NMR are assigned as follows: brs, broad singlet; s, singlet; $\mathrm{d}$, doublet; $\mathrm{t}$, triplet; $\mathrm{q}$, quartet; quint, quintet; sext, sextet; $\mathrm{m}$, multiplet; or as a combination (e.g., dd, dt, td, etc.). The coupling constant $(J)$ in hertz, integration, and proton count was also reported.

\subsubsection{Synthesis of Brominated DHPs' Intermediates 30-35}

The 5-Br DHPs were synthesized from furanones 14-15 and 27-29. Furanones (1 mmol) were dissolved in DCM $(5 \mathrm{~mL})$ and the solution was cooled in an ice bath before the addition of propylamine ( 4 eq., $4 \mathrm{mmol}$ ), and then the reaction mixture was left to stir for $2 \mathrm{~h}$. The solvent was evaporated and the oil residue was dehydrated with TFA (1 eq.) to give intermediates 30 to 34, which were purified by flash chromatography with 50\% dichloromethane in hexane to give intermediate DHPs 30 to $\mathbf{3 4}$. Synthetic procedures were reported of other intermediates 16, 17, and 35 previously [7,43].

\subsubsection{Sonogashira Coupling Reaction Procedure}

A mixture of acetylene (2.5 eq.) and TEA (1 eq.) in THF was purged with argon or nitrogen for $20 \mathrm{~min}$ before the addition of the 5-bromo DHPs ( $1 \mathrm{mmol}), \mathrm{CuI}(0.1 \mathrm{eq}$.$) ,$ and $\mathrm{PdCl}_{2}\left(\mathrm{PPh}_{3}\right)_{2}(0.1$ eq. $)$, and the mixture was heated at $60{ }^{\circ} \mathrm{C}$ for $18 \mathrm{~h}$. The $\mathrm{THF}$ in the reaction mixture was evaporated, redissolved in DCM, washed with $2 \mathrm{M} \mathrm{HCl}(5 \mathrm{~mL} \times 2)$, and the organic layer was dried over sodium sulphate. The crude mixtures were purified by flash chromatography using gradient solvent mixture of dichloromethane and hexane (10 to $50 \%$ gradient).

\subsection{Compounds' Full Characterizations}

\section{5-(Dibromomethylene)-3-ethyl-1-propyl-1,5-dihydro-2H-pyrrol-2-one (30)}

Yellow semi-solid (30\%); ${ }^{1} \mathrm{H}$ NMR $\left(\mathrm{CDCl}_{3}, 400 \mathrm{MHz}\right): \delta 0.91\left(\mathrm{t}, J=8.0 \mathrm{~Hz}, 3 \mathrm{H}, \mathrm{CH}_{3}\right)$, $1.20\left(\mathrm{t}, J=8.0 \mathrm{~Hz}, 3 \mathrm{H}, \mathrm{CH}_{3}\right), 1.61-1.70\left(\mathrm{~m}, 2 \mathrm{H}, \mathrm{CH}_{2}\right), 2.34-2.38\left(\mathrm{~m}, 2 \mathrm{H}, \mathrm{CH}_{2}\right), 3.93-3.97(\mathrm{~m}$, $\left.2 \mathrm{H}, \mathrm{CH}_{2}\right), 7.02(\mathrm{~s}, 1 \mathrm{H}, \mathrm{C} 4-\mathrm{H}) ;{ }^{13} \mathrm{C} \mathrm{NMR}\left(\mathrm{CDCl}_{3}, 100 \mathrm{MHz}\right): \delta 10.8\left(\mathrm{CH}_{3}\right), 11.7\left(\mathrm{CH}_{3}\right)$, $18.9\left(\mathrm{CH}_{2}\right), 23.4\left(\mathrm{CH}_{2}\right), 42.3\left(\mathrm{CH}_{2}\right), 73.5(\mathrm{C}), 131.3(\mathrm{CH}), 140.2(\mathrm{C}), 140.7(\mathrm{C}), 171.9(\mathrm{C}=\mathrm{O})$; IR (ATR): $\nu_{\max } 753,878,1044,1451,1688,2925,2967 \mathrm{~cm}^{-1} ; \mathrm{UV}-\mathrm{VIS}$ (MeOH): $\lambda_{\max } 285 \mathrm{~nm}$ ( $\varepsilon$ 13,859 $\left.\mathrm{cm}^{-1} \mathrm{M}^{-1}\right)$; HRMS $\left(\mathrm{C}_{10} \mathrm{H}_{13}{ }^{79} \mathrm{Br}_{2} \mathrm{NO}\right)$ calcd $\mathrm{m} / \mathrm{z} 343.9256[\mathrm{M}+\mathrm{Na}]^{+}$, obsd m/z $343.9258[\mathrm{M}+\mathrm{Na}]^{+}$and HRMS $\left(\mathrm{C}_{10} \mathrm{H}_{13}{ }^{81} \mathrm{Br}_{2} \mathrm{NO}\right)$ calcd $\mathrm{m} / \mathrm{z} 347.9215[\mathrm{M}+\mathrm{Na}]^{+}, \mathrm{obsd} \mathrm{m} / \mathrm{z}$ $349.9215[\mathrm{M}+\mathrm{Na}]^{+}$.

\section{3-Butyl-5-(Dibromomethylene)-1-propyl-1,5-dihydro-2H-pyrrol-2-one (31)}

Yellow semi-solid (61\%); ${ }^{1} \mathrm{H} \mathrm{NMR}\left(\mathrm{CDCl}_{3}, 400 \mathrm{MHz}\right): \delta 0.94-0.98\left(\mathrm{~m}, 6 \mathrm{H}, \mathrm{CH}_{3} \times 2\right)$, 1.28-1.44 (m, 2H, CH $), 1.54-1.70\left(\mathrm{~m}, 6 \mathrm{H}, \mathrm{CH}_{2} \times 3\right), 2.32-2.36\left(\mathrm{~m}, 2 \mathrm{H}, \mathrm{CH}_{2}\right), 3.93-3.95(\mathrm{~m}$, $\left.2 \mathrm{H}, \mathrm{CH}_{2}\right) 7.02(\mathrm{~s}, 1 \mathrm{H}, \mathrm{C} 4-\mathrm{H}) ;{ }^{13} \mathrm{C} \mathrm{NMR}\left(\mathrm{CDCl}_{3}, 100 \mathrm{MHz}\right): \delta 10.8\left(\mathrm{CH}_{3}\right), 13.8\left(\mathrm{CH}_{3}\right)$, $22.4\left(\mathrm{CH}_{2}\right), 23.4\left(\mathrm{CH}_{2}\right), 25.2\left(\mathrm{CH}_{2}\right), 29.6\left(\mathrm{CH}_{2}\right), 42.3\left(\mathrm{CH}_{2}\right), 73.1(\mathrm{C}), 131.8(\mathrm{CH}), 138.8(\mathrm{C})$, 140.7 (C), 172.1 (C); IR (ATR): $v_{\max } 694,851,1188,1345,1508,1709,3171 \mathrm{~cm}^{--1}$; UV-VIS $(\mathrm{MeOH}): \lambda_{\max } 285 \mathrm{~nm}\left(\varepsilon \mathrm{13}, 920 \mathrm{~cm}^{-1} \mathrm{M}^{-1}\right)$; HRMS $\left(\mathrm{C}_{12} \mathrm{H}_{17}{ }^{79} \mathrm{Br}_{2} \mathrm{NO}\right)$ calcd m/z 349.9750 $[\mathrm{M}+\mathrm{H}]^{+}$, obsd m/z $349.9751[\mathrm{M}+\mathrm{H}]^{+}$and HRMS $\left(\mathrm{C}_{12} \mathrm{H}_{17}{ }^{81} \mathrm{Br}_{2} \mathrm{NO}\right)$ calcd $\mathrm{m} / \mathrm{z} 353.9709$ $[\mathrm{M}+\mathrm{H}]^{+}$, obsd $\mathrm{m} / \mathrm{z} 353.9709[\mathrm{M}+\mathrm{H}]^{+}$.

5-(Dibromomethylene)-3-hexyl-1-propyl-1,5-dihydro-2H-pyrrol-2-one (32)

Yellow semi-solid (58\%); ${ }^{1} \mathrm{H}$ NMR $\left(\mathrm{CDCl}_{3}, 400 \mathrm{MHz}\right): \delta 0.91(\mathrm{t}, J=8.0 \mathrm{~Hz}, 6 \mathrm{H}$, $\left.\mathrm{CH}_{3} \times 2\right), 1.30-1.40\left(\mathrm{~m}, 6 \mathrm{H}, \mathrm{CH}_{2} \times 3\right), 1.54-1.68\left(\mathrm{~m}, 4 \mathrm{H}, \mathrm{CH}_{2} \times 2\right), 2.31-2.35(\mathrm{~m}, 2 \mathrm{H}$, $\left.\mathrm{CH}_{2}\right), 3.93-3.97\left(\mathrm{~m}, 2 \mathrm{H}, \mathrm{CH}_{2}\right), 7.02(\mathrm{~s}, \mathrm{C} 4-\mathrm{H}) ;{ }^{13} \mathrm{C} \mathrm{NMR}\left(\mathrm{CDCl}_{3}, 100 \mathrm{MHz}\right): \delta 10.9\left(\mathrm{CH}_{3}\right)$, $14.1\left(\mathrm{CH}_{3}\right), 22.5\left(\mathrm{CH}_{2}\right), 23.4\left(\mathrm{CH}_{2}\right), 25.5(\mathrm{CH} 2), 27.5\left(\mathrm{CH}_{2}\right), 28.9\left(\mathrm{CH}_{2}\right), 31.5\left(\mathrm{CH}_{2}\right), 42.3$ $\left(\mathrm{CH}_{2}\right), 70.5(\mathrm{C}), 131.8(\mathrm{CH}), 138.9(\mathrm{C}), 140.7(\mathrm{C}), 172.1(\mathrm{C}=\mathrm{O})$; IR (ATR): $v_{\max } 753,816,1172$, 1440, 1594, 1694, $2923 \mathrm{~cm}^{-1}$; UV-VIS (MeOH): $\lambda_{\max } 285 \mathrm{~nm}\left(\varepsilon 53,601 \mathrm{~cm}^{-1} \mathrm{M}^{-1}\right)$; HRMS $\left(\mathrm{C}_{14} \mathrm{H}_{21} \mathrm{Br}_{2} \mathrm{NO}\right)$ calcd $\mathrm{m} / \mathrm{z} 378.0063[\mathrm{M}+\mathrm{H}]^{+}$, obsd $\mathrm{m} / \mathrm{z} 378.0065[\mathrm{M}+\mathrm{H}]^{+}$and HRMS $\left(\mathrm{C}_{14} \mathrm{H}_{21}{ }^{81} \mathrm{Br}_{2} \mathrm{NO}\right)$ calcd $\mathrm{m} / \mathrm{z} 382.0022[\mathrm{M}+\mathrm{H}]^{+}$, obsd m/z $382.0023[\mathrm{M}+\mathrm{H}]^{+}$.

5-(Dibromomethylene)-3-heptyl-1-propyl-1,5-dihydro-2 $\mathrm{H}$-pyrrol-2-one (33)

Yellow semi-solid (87\%); ${ }^{1} \mathrm{H} \mathrm{NMR}\left(\mathrm{CDCl}_{3}, 400 \mathrm{MHz}\right): \delta 0.90-0.93\left(\mathrm{~m}, 6 \mathrm{H}, \mathrm{CH}_{3}\right)$, 1.28-1.36 (m, 10H, CH 2$), 1.61-1.66\left(\mathrm{~m}, 2 \mathrm{H}, \mathrm{CH}_{2}\right) 2.31-2.36\left(\mathrm{~m}, 2 \mathrm{H}, \mathrm{CH}_{2}\right), 3.95(\mathrm{t}, J=8.0 \mathrm{~Hz}$, 
$\left.\mathrm{CH}_{2}\right), 7.02(\mathrm{~s}, 1 \mathrm{H}, \mathrm{CH}) ;{ }^{13} \mathrm{C} \mathrm{NMR}\left(\mathrm{CDCl}_{3}, 100 \mathrm{MHz}\right): \delta 10.9\left(\mathrm{CH}_{3}\right), 14.1\left(\mathrm{CH}_{3}\right), 22.6\left(\mathrm{CH}_{2}\right)$, 23.4 $\left(\mathrm{CH}_{2}\right), 25.5\left(\mathrm{CH}_{2}\right), 27.5\left(\mathrm{CH}_{2}\right), 28.9\left(\mathrm{CH}_{2}\right), 29.3\left(\mathrm{CH}_{2}\right), 31.7\left(\mathrm{CH}_{2}\right), 42.3\left(\mathrm{CH}_{2}\right), 73.5(\mathrm{C})$; UV-VIS (MeOH): $\lambda_{\max } 285 \mathrm{~nm}\left(\varepsilon 56,642 \mathrm{~cm}^{-1} \mathrm{M}^{-1}\right)$; HRMS $\left(\mathrm{C}_{15} \mathrm{H}_{23} \mathrm{Br}_{2} \mathrm{NO}\right)$ calcd m/z $392.0219[\mathrm{M}+\mathrm{H}]^{+}$, obsd m/z $392.0219[\mathrm{M}+\mathrm{H}]^{+}$and HRMS $\left(\mathrm{C}_{15} \mathrm{H}_{23}{ }^{81} \mathrm{Br}_{2} \mathrm{NO}\right)$ calcd $\mathrm{m} / \mathrm{z}$ $396.0178[\mathrm{M}+\mathrm{H}]^{+}$, obsd $\mathrm{m} / \mathrm{z} 396.0175[\mathrm{M}+\mathrm{H}]^{+}$.

5-(Dibromomethylene)-3-octyl-1-propyl-1,5-dihydro-2H-pyrrol-2-one (34)

Yellow semi-solid (68\%); ${ }^{1} \mathrm{H}$ NMR $\left(\mathrm{CDCl}_{3}, 400 \mathrm{MHz}\right): \delta 0.90-0.97\left(\mathrm{~m}, 6 \mathrm{H}, \mathrm{CH}_{3}\right)$, 1.90-1.93 (m, 12H, $\left.\mathrm{CH}_{2}\right), 1.57-2.35\left(\mathrm{~m}, \mathrm{CH}_{2}\right), 2.33\left(\mathrm{t}, J=8.0 \mathrm{~Hz}, 2 \mathrm{H}, \mathrm{CH}_{2}\right), 3.95(\mathrm{t}, J=8.0 \mathrm{~Hz}$, $\left.2 \mathrm{H}, \mathrm{CH}_{2}\right), 7.03(\mathrm{~s}, 1 \mathrm{H}, \mathrm{CH}) ;{ }^{13} \mathrm{C} \mathrm{NMR}\left(\mathrm{CDCl}_{3}, 100 \mathrm{MHz}\right): \delta 10.9\left(\mathrm{CH}_{3}\right), 14.1\left(\mathrm{CH}_{3}\right), 22.7\left(\mathrm{CH}_{2}\right)$, 23.4 $\left(\mathrm{CH}_{2}\right), 25.5\left(\mathrm{CH}_{2}\right), 27.5\left(\mathrm{CH}_{2}\right), 29.2\left(\mathrm{CH}_{2}\right), 29.3\left(\mathrm{CH}_{2}\right), 31.8\left(\mathrm{CH}_{2}\right), 42.4\left(\mathrm{CH}_{2}\right), 73.9(\mathrm{C})$, 131.9 (CH), 138.8 (C), 140.7 (C), 172.2 (C=O); IR (ATR): $v_{\max } 751,824,1132,1197,1459,1687$, $2922 \mathrm{~cm}^{-1}$; UV-VIS (MeOH): $\lambda_{\max } 285 \mathrm{~nm}\left(\varepsilon 15,452 \mathrm{~cm}^{-1} \mathrm{M}^{-1}\right)$; HRMS $\left(\mathrm{C}_{16} \mathrm{H}_{25}{ }^{79} \mathrm{Br}_{2} \mathrm{NO}\right)$ calcd $\mathrm{m} / \mathrm{z} 406.0376[\mathrm{M}+\mathrm{H}]^{+}$, obsd $\mathrm{m} / \mathrm{z} 406.0380[\mathrm{M}+\mathrm{H}]^{+}$and HRMS $\left(\mathrm{C}_{16} \mathrm{H}_{25}{ }^{81} \mathrm{Br}_{2} \mathrm{NO}\right)$ calcd $\mathrm{m} / \mathrm{z} 410.0335[\mathrm{M}+\mathrm{H}]^{+}$, obsd $\mathrm{m} / \mathrm{z} 410.0338[\mathrm{M}+\mathrm{H}]^{+}$.

\section{DHP Acetylene Analogues}

3-Butyl-5-(1,5-diphenylpenta-1,4-diyn-3-ylidene)-1,5-dihydro-2H-pyrrol-2-one (18)

Yellow solid (72\%); m.p. $215^{\circ} \mathrm{C} ;{ }^{1} \mathrm{H}$ NMR $\left(\mathrm{CDCl}_{3}, 400 \mathrm{MHz}\right): \delta 0.93(\mathrm{t}, J=8.0 \mathrm{~Hz}, 3 \mathrm{H}$, $\left.\mathrm{CH}_{3}\right), 1.38-1.48\left(\mathrm{~m}, 2 \mathrm{H}, \mathrm{CH}_{3}\right), 1.58-1.61\left(\mathrm{~m}, 2 \mathrm{H}, \mathrm{CH}_{2}\right), 2.40-2.42\left(\mathrm{q}, J=8.0 \mathrm{~Hz}, 2 \mathrm{H}, \mathrm{CH}_{2}\right)$, 7.11 (s, 1H, C4-H), 7.26-7.38 (m, 6H, ArH), 7.53-7.57 (m, 4H, ArH), 8.06 (s, NH); ${ }^{13} \mathrm{C}$ NMR $\left(\mathrm{CDCl}_{3}, 100 \mathrm{MHz}\right): \delta 13.9\left(\mathrm{CH}_{3}\right), 22.5\left(\mathrm{CH}_{2}\right), 25.4\left(\mathrm{CH}_{2}\right), 29.9\left(\mathrm{CH}_{2}\right), 65.9\left(=\mathrm{C}-\mathrm{Br}_{2}\right), 83.8$ (C), $86.9(\mathrm{C}), 93.5(\mathrm{C}), 97.5(\mathrm{C}), 122.1(\mathrm{C}), 122.5(\mathrm{C}), 128.0(\mathrm{C}), 128.4(\mathrm{CH}), 128.5(\mathrm{CH}), 128.8$ (C), $129.2(\mathrm{C}), 131.6(\mathrm{CH}), 131.7(\mathrm{CH}), 141.1(\mathrm{C}), 148.6(\mathrm{C}), 170.6$ (C=O); IR (ATR): $v_{\max } 752$, 848, 1124, 1486, 1685, $3155 \mathrm{~cm}^{-1}$; UV-VIS (MeOH): $\lambda_{\max } 390 \mathrm{~nm}\left(\varepsilon 12,962 \mathrm{~cm}^{-1} \mathrm{M}^{-1}\right) 295$ $(10,741)$; HRMS $\left(\mathrm{C}_{25} \mathrm{H}_{21} \mathrm{NO}\right)$ calcd m/z $352.1696[\mathrm{M}+\mathrm{H}]^{+}$, obsd m/z $352.1695[\mathrm{M}+\mathrm{H}]^{+}$.

3-butyl-5-(1,5-di-p-tolylpenta-1,4-diyn-3-ylidene)-1,5-dihydro-2H-pyrrol-2-one (19)

Yellow solid (71\%); m.p. $148{ }^{\circ} \mathrm{C} ;{ }^{1} \mathrm{H}$ NMR $\left(\mathrm{CDCl}_{3}, 400 \mathrm{MHz}\right): \delta 0.97(\mathrm{t}, J=8.0 \mathrm{~Hz}$, $\left.3 \mathrm{H}, \mathrm{CH}_{3}\right), 1.41-1.46\left(\mathrm{~m}, 2 \mathrm{H}, \mathrm{CH}_{2}\right), 1.59-1.65\left(\mathrm{~m}, 4 \mathrm{H}, \mathrm{CH}_{2}\right), 2.42-2.46\left(\mathrm{~m}, 2 \mathrm{H}, \mathrm{CH}_{2}\right), 7.13$ (s, 1H, C4-H), 7.19-7.21 (m, 4H, ArH), 7.28-7.46 (m, 4H, ArH), 7.87 (s, NH); ${ }^{13} \mathrm{C}$ NMR $\left(\mathrm{CDCl}_{3}, 100 \mathrm{MHz}\right): \delta 13.8\left(\mathrm{CH}_{3}\right), 21.6\left(\mathrm{CH}_{2}\right), 22.5\left(\mathrm{CH}_{2}\right), 25.4\left(\mathrm{CH}_{2}\right), 30.0\left(\mathrm{CH}_{2}\right), 83.5$ (=C-Br $), 87.4(\mathrm{C}), 87.4(\mathrm{C}), 93.7(\mathrm{C}), 97.8(\mathrm{C}), 119.0(\mathrm{C}), 128.0(\mathrm{C}), 129.2(\mathrm{CH}), 131.5(\mathrm{CH})$, 139.1 (C), 139.5 (C), 141.8 (C), 148.0 (C), 170.5 (C=O); IR (ATR): $v_{\max } 753,812,1090,1508$, 1685, $2959 \mathrm{~cm}^{-1}$; UV-VIS (MeOH): $\lambda_{\max } 390 \mathrm{~nm}\left(\varepsilon 5560 \mathrm{~cm}^{-1} \mathrm{M}^{-1}\right) 300$ (5370); HRMS $\left(\mathrm{C}_{27} \mathrm{H}_{25} \mathrm{NO}\right)$ calcd $\mathrm{m} / \mathrm{z} 380.2009[\mathrm{M}+\mathrm{H}]^{+}$, obsd m/z $380.2009[\mathrm{M}+\mathrm{H}]^{+}$.

5-(1,5-Diphenylpenta-1,4-diyn-3-ylidene)-3-hexyl-1,5-dihydro-2H-pyrrol-2-one (20)

Yellow solid (62\%); m.p. $156{ }^{\circ} \mathrm{C} ;{ }^{1} \mathrm{H}$ NMR $\left(\mathrm{CDCl}_{3}, 400 \mathrm{MHz}\right): \delta 0.92(\mathrm{t}, J=8.0 \mathrm{~Hz}, 3 \mathrm{H}$, $\left.\mathrm{CH}_{3}\right), 1.28-1.40\left(\mathrm{~m}, 6 \mathrm{H}, \mathrm{CH}_{2}\right), 1.42-1.66\left(\mathrm{~m}, 2 \mathrm{H}, \mathrm{CH}_{2}\right), 2.42-2.46\left(\mathrm{~m}, 2 \mathrm{H}, \mathrm{CH}_{2}\right), 7.14(\mathrm{~s}, 1 \mathrm{H}$, $\mathrm{C} 4-\mathrm{H}), 7.28-7.41(\mathrm{~m}, 6 \mathrm{H}, \mathrm{ArH}), 7.56-7.60(\mathrm{~m}, 4 \mathrm{H}, \mathrm{ArH}), 8.11(\mathrm{~s}, \mathrm{NH}) ;{ }^{13} \mathrm{C} \mathrm{NMR}\left(\mathrm{CDCl}_{3}\right.$, $100 \mathrm{MHz}): \delta 14.1\left(\mathrm{CH}_{3}\right), 22.5\left(\mathrm{CH}_{2}\right), 25.7\left(\mathrm{CH}_{2}\right), 27.9\left(\mathrm{CH}_{2}\right), 29.1\left(\mathrm{CH}_{2}\right), 31.6\left(\mathrm{CH}_{2}\right), 83.8(\mathrm{C})$, $86.9(\mathrm{C}), 93.5(\mathrm{C}), 97.5(\mathrm{C}), 122.1(\mathrm{C}), 128.0(\mathrm{C}), 128.5(\mathrm{CH}), 128.9(\mathrm{C}), 129.2(\mathrm{C}), 131.6(\mathrm{CH})$, 141.1 (C), 148.6 (C), 170.6 (C=O); IR (ATR): $v_{\max } 752,845,1096,1370,1488,1684,2918 \mathrm{~cm}^{-1}$; UV-VIS (MeOH): $\lambda_{\max } 390 \mathrm{~nm}\left(\varepsilon 5655 \mathrm{~cm}^{-1} \mathrm{M}^{-1}\right), 295$ (4934); HRMS $\left(\mathrm{C}_{27} \mathrm{H}_{25} \mathrm{NO}\right)$ calcd $\mathrm{m} / \mathrm{z} 380.2009[\mathrm{M}+\mathrm{H}]^{+}$, obsd $\mathrm{m} / \mathrm{z} 380.2010[\mathrm{M}+\mathrm{H}]^{+}$.

(Z)-4-Phenyl-5-(3-phenylprop-2-yn-1-ylidene)-1,5-dihydro-2H-pyrrol-2-one (24)

Brown semi-solid (90\%); ${ }^{1} \mathrm{H}$ NMR $\left(\mathrm{CDCl}_{3}, 400 \mathrm{MHz}\right): \delta 5.59(\mathrm{~s}, 1 \mathrm{H}, \mathrm{CH}), 6.25(\mathrm{~s}, 1 \mathrm{H}$, $\mathrm{C} 3-\mathrm{H}), 7.37-7.47(\mathrm{~m}, 3 \mathrm{H}, \mathrm{ArH}), 7.48-7.56(\mathrm{~m}, 7 \mathrm{H}, \mathrm{ArH}), 8.30(\mathrm{~s}, 1 \mathrm{H}, \mathrm{NH}),{ }^{13} \mathrm{C} \mathrm{NMR}\left(\mathrm{CDCl}_{3}\right.$, $100 \mathrm{MHz}): \delta 84.9(\mathrm{C}), 92.9(\mathrm{C}), 101.4(\mathrm{C}), 121.6(\mathrm{ArC}), 122.5(\mathrm{CH}), 128.5(\mathrm{ArCH} \times 2), 125.6$ $(\mathrm{ArCH}), 128.9(\mathrm{ArCH} \times 2), 129.1(\mathrm{ArCH}), 129.7(\mathrm{ArCH}), 131.3(\mathrm{ArC}), 131.7(\mathrm{ArCH}), 145.9$ (C), 150.5 (C), 169.5 (C=O); IR (ATR): $v_{\max } 691,758,1682,3140 \mathrm{~cm}^{-1}$; UV-VIS (MeOH): $\lambda_{\max }$ $363 \mathrm{~nm}\left(\varepsilon 29,137 \mathrm{~cm}^{-1} \mathrm{M}^{-1}\right)$; HRMS $\left(\mathrm{C}_{19} \mathrm{H}_{13} \mathrm{NO}\right)$ calcd m/z $294.0889[\mathrm{M}+\mathrm{Na}]^{+}$, obsd m/z $294.0887[\mathrm{M}+\mathrm{Na}]^{+}$.

(Z)-4-(2-Fluorophenyl)-5-(3-phenylprop-2-yn-1-ylidene)-1,5-dihydro-2H-pyrrol-2-one (25)

Red semi-solid (75\%); ${ }^{1} \mathrm{H}$ NMR $\left(\mathrm{CDCl}_{3}, 400 \mathrm{MHz}\right): \delta 5.47(\mathrm{~s}, 1 \mathrm{H}, \mathrm{CH}), 6.35(\mathrm{~s}, 1 \mathrm{H}$, C3-H), 7.21-7.28 (m, 2H, ArH), 7.38-7.39 (m, 7H, ArH), 7.45-7.53 (m, 4H, ArH), 8.53 (s, 
$1 \mathrm{H}, \mathrm{NH}) ;{ }^{13} \mathrm{C} \mathrm{NMR}\left(\mathrm{CDCl}_{3}, 100 \mathrm{MHz}\right): \delta 84.8(\mathrm{C}), 92.8(\mathrm{C}), 101.4(\mathrm{C}), 116.3(\mathrm{ArCH}), 118.9$ $(\mathrm{ArC}), 122.4(\mathrm{CH}), 124.2(\mathrm{ArC}), 124.3(\mathrm{ArCH}), 128.0(\mathrm{ArC}), 128.6(\mathrm{ArCH} \times 2), 129.1(\mathrm{ArCH})$, 130.8 (ArCH), $131.4(\mathrm{ArCH}), 131.8(\mathrm{ArCH} \times 2), 143.7(\mathrm{C}), 158.9(\mathrm{C}), 169.5(\mathrm{C}=\mathrm{O})$; IR (ATR): $v_{\max } 745,831,1688,3139 \mathrm{~cm}^{-1}$; UV-VIS (MeOH): $\lambda_{\max } 364 \mathrm{~nm}\left(\varepsilon 36,707 \mathrm{~cm}^{-1} \mathrm{M}^{-1}\right)$; HRMS $\left(\mathrm{C}_{19} \mathrm{H}_{12} \mathrm{~F}_{1} \mathrm{NO}\right)$ calcd m/z $312.0795[\mathrm{M}+\mathrm{Na}]^{+}$, obsd m/z $312.0795[\mathrm{M}+\mathrm{Na}]^{+}$.

(Z)-4-(4-Bromophenyl)-5-(3-phenylprop-2-yn-1-ylidene)-1,5-dihydro-2H-pyrrol-2-one (26) Yellow semi-solid (35\%); ${ }^{1} \mathrm{H}$ NMR $\left(\mathrm{CDCl}_{3}, 400 \mathrm{MHz}\right): \delta 5.54(\mathrm{~s}, 1 \mathrm{H}, \mathrm{CH}), 6.25(\mathrm{~s}, 1 \mathrm{H}$, C3-H), 7.31-7.40 (m, 5H, ArH), 7.51-7.54 (m, 2H, ArH), 7.61-7.65 (m, 2H, ArH), 8.09 (s, 1H, $\mathrm{NH}) ;{ }^{13} \mathrm{C} \mathrm{NMR}\left(\mathrm{CDCl}_{3}, 100 \mathrm{MHz}\right): \delta 84.7(\mathrm{C}), 92.9(\mathrm{C}), 101.7(\mathrm{C}), 121.8(\mathrm{CH}), 122.3(\mathrm{ArC})$, 124.3 $(\mathrm{ArC}), 128.6(\mathrm{ArCH} \times 2), 129.2(\mathrm{ArCH}), 130.0(\mathrm{ArCH} \times 2), 130.0(\mathrm{ArC}), 131.6(\mathrm{ArCH})$, 132.2 (ArCH), $145.5(\mathrm{C}), 149.2(\mathrm{C}), 169.3(\mathrm{C}=\mathrm{O})$; IR (ATR): $v_{\max } 750,817,1682,3138 \mathrm{~cm}^{-1}$; UV-VIS (MeOH): $\lambda_{\max } 367 \mathrm{~nm}\left(\varepsilon 34,700 \mathrm{~cm}^{-1} \mathrm{M}^{-1}\right)$; HRMS $\left(\mathrm{C}_{19} \mathrm{H}_{12}{ }^{79} \mathrm{Br}_{1} \mathrm{NO}\right)$ calcd m/z $371.9995[\mathrm{M}+\mathrm{Na}]^{+}$, obsd m/z $371.9995[\mathrm{M}+\mathrm{Na}]^{+}$and HRMS $\left(\mathrm{C}_{19} \mathrm{H}_{12}{ }^{81} \mathrm{Br}_{1} \mathrm{NO}\right)$ calcd m/z $373.9974[\mathrm{M}+\mathrm{Na}]^{+}$, obsd m/z $373.9974[\mathrm{M}+\mathrm{Na}]^{+}$.

5-(1,5-Diphenylpenta-1,4-diyn-3-ylidene)-3-ethyl-1-propyl-1,5-dihydro-2H-pyrrol-2-one (36)

Yellow semi-solid (37\%); ${ }^{1} \mathrm{H}$ NMR $\left(\mathrm{CDCl}_{3}, 400 \mathrm{MHz}\right): \delta 0.93\left(\mathrm{t}, J=8.0 \mathrm{~Hz}, 3 \mathrm{H}, \mathrm{CH}_{3}\right)$, 1.23-1.29 (m, $\left.4 \mathrm{H}, \mathrm{CH}_{3}\right), 1.78-1.83\left(\mathrm{~m}, 2 \mathrm{H}, \mathrm{CH}_{2}\right), 2.44-2.50\left(\mathrm{~m}, 2 \mathrm{H}, \mathrm{CH}_{2}\right), 4.12-4.16(\mathrm{~m}, 2 \mathrm{H}$, $\left.\mathrm{CH}_{2}\right), 7.22(\mathrm{~s}, 1 \mathrm{H}, \mathrm{C} 4-\mathrm{H}), 7.38-7.40(\mathrm{~m}, 6 \mathrm{H}, \mathrm{ArH}), 7.52-7.57(\mathrm{~m}, 4 \mathrm{H}, \mathrm{ArH}) ;{ }^{13} \mathrm{C} \mathrm{NMR}\left(\mathrm{CDCl}_{3}\right.$, $100 \mathrm{MHz}): \delta 11.2\left(\mathrm{CH}_{3}\right), 11.9\left(\mathrm{CH}_{3}\right), 19.0\left(\mathrm{CH}_{2}\right), 23.4\left(\mathrm{CH}_{2}\right), 42.2\left(\mathrm{CH}_{2}\right), 85.4(\mathrm{C}), 86.2(\mathrm{C})$, $92.3(\mathrm{C}), 96.2(\mathrm{C}), 122.6(\mathrm{C}), 128.5(\mathrm{CH}), 128.6(\mathrm{C}), 129.0(\mathrm{C}), 131.4(\mathrm{C}), 131.6(\mathrm{C}), 139.7(\mathrm{CH})$, 139.7 (C), 148.4 (C), 170.9 (C=O), IR (ATR): $v_{\max } 752,1040,1154,1440,1569,1689,2963 \mathrm{~cm}^{-1}$. UV-VIS (MeOH): $\lambda_{\max } 395 \mathrm{~nm}\left(\varepsilon 36,349 \mathrm{~cm}^{-1} \mathrm{M}^{-1}\right), 295(31,086) ;$ HRMS $\left(\mathrm{C}_{26} \mathrm{H}_{23} \mathrm{NO}\right)$ calcd $\mathrm{m} / \mathrm{z} 366.1852[\mathrm{M}+\mathrm{H}]^{+}$, obsd $\mathrm{m} / \mathrm{z} 366.1854[\mathrm{M}+\mathrm{H}]^{+}$.

5-(1,5-Di-p-tolylpenta-1,4-diyn-3-ylidene)-3-ethyl-1-propyl-1,5-dihydro-2H-pyrrol-2-one (37)

Yellow semi-solid (38\%); ${ }^{1} \mathrm{H}$ NMR $\left(\mathrm{CDCl}_{3}, 400 \mathrm{MHz}\right): \delta 0.92\left(\mathrm{t}, J=8.0 \mathrm{~Hz}, 3 \mathrm{H}, \mathrm{CH}_{3}\right)$, 1.22-1.26 (m, 3H, $\left.\mathrm{CH}_{3}\right), 1.76-1.82\left(\mathrm{~m}, 2 \mathrm{H}, \mathrm{CH}_{2}\right), 2.40-2.43\left(\mathrm{bs}, 6 \mathrm{H}, \mathrm{CH}_{3}\right), 2.44-2.47(\mathrm{~m}, 2 \mathrm{H}$, $\left.\mathrm{CH}_{2}\right), 4.11-4.15\left(\mathrm{~m}, 2 \mathrm{H}, \mathrm{CH}_{2}\right), 7.18-7.22(\mathrm{~m}, 5 \mathrm{H}, \mathrm{C} 4-\mathrm{H} \& \mathrm{ArH}), 7.42-7.46(\mathrm{~m}, 4 \mathrm{H}, \mathrm{ArH})$; ${ }^{13} \mathrm{C} \mathrm{NMR}\left(\mathrm{CDCl}_{3}, 100 \mathrm{MHz}\right): \delta 11.2\left(\mathrm{CH}_{3}\right), 12.0\left(\mathrm{CH}_{3}\right), 19.0\left(\mathrm{CH}_{2}\right), 21.6\left(\mathrm{CH}_{2}\right), 23.4\left(\mathrm{CH}_{2}\right)$, $42.2\left(\mathrm{CH}_{2}\right), 85.0(\mathrm{C}), 86.7(\mathrm{C}), 87.0(\mathrm{C}), 92.4(\mathrm{C}), 96.5(\mathrm{C}), 119.6(\mathrm{C}), 129.0(\mathrm{CH}), 129.2(\mathrm{CH})$, $131.4(\mathrm{CH}), 138.9$ (C), $139.4(\mathrm{C}), 147.9$ (C), 170.9 (C=O); IR (ATR): $v_{\max } 813,853,1197,1442$, 1565, 1694, $2924 \mathrm{~cm}^{-1}$; UV-VIS (MeOH): $\lambda_{\max } 395 \mathrm{~nm}\left(\varepsilon 6265 \mathrm{~cm}^{-1} \mathrm{M}^{-1}\right), 393$ (6186); HRMS $\left(\mathrm{C}_{28} \mathrm{H}_{27} \mathrm{NO}\right)$ calcd m/z $394.2165[\mathrm{M}+\mathrm{H}]^{+}$, obsd m/z $394.2165[\mathrm{M}+\mathrm{H}]^{+}$.

3-Butyl-5-(1,5-diphenylpenta-1,4-diyn-3-ylidene)-1-propyl-1,5-dihydro-2H-pyrrol-2-one (38)

Yellow semi-solid (48\%); ${ }^{1} \mathrm{H}$ NMR $\left(\mathrm{CDCl}_{3}, 400 \mathrm{MHz}\right): \delta 0.91-0.99\left(\mathrm{~m}, 6 \mathrm{H}, \mathrm{CH}_{3}\right)$, 1.40-1.46 (m, 2H, $\left.\mathrm{CH}_{2}\right), 1.52-1.66\left(\mathrm{~m}, 2 \mathrm{H}, \mathrm{CH}_{2}\right), 1.78-1.83\left(\mathrm{~m}, 2 \mathrm{H}, \mathrm{CH}_{2}\right), 2.42-2.46(\mathrm{~m}, 2 \mathrm{H}$, $\left.\mathrm{CH}_{2}\right), 4.12-4.16\left(\mathrm{~m}, 2 \mathrm{H}, \mathrm{CH}_{2}\right), 7.22(\mathrm{~s}, 1 \mathrm{H}, \mathrm{C} 4-\mathrm{H}), 7.38-7.40(\mathrm{~m}, 6 \mathrm{H}, \mathrm{ArH}), 7.52-7.57(\mathrm{~m}, 4 \mathrm{H}$, $\mathrm{ArH}) ;{ }^{13} \mathrm{C} \mathrm{NMR}\left(\mathrm{CDCl}_{3}, 100 \mathrm{MHz}\right): \delta 11.2\left(\mathrm{CH}_{3}\right), 13.9\left(\mathrm{CH}_{3}\right), 22.5\left(\mathrm{CH}_{2}\right), 23.5\left(\mathrm{CH}_{2}\right), 25.4$ $\left(\mathrm{CH}_{2}\right), 29.9\left(\mathrm{CH}_{2}\right), 42.2\left(\mathrm{CH}_{2}\right), 85.5(\mathrm{C}), 86.2(\mathrm{C}), 86.5(\mathrm{C}), 92.2(\mathrm{C}), 96.2(\mathrm{C}), 122.6(\mathrm{C}), 122.8$ (C), $128.4(\mathrm{CH}), 128.5(\mathrm{CH}), 128.7(\mathrm{C}), 129.0(\mathrm{C}), 129.7(\mathrm{C}), 131.4(\mathrm{CH}), 131.5(\mathrm{CH}), 138.3(\mathrm{C})$, 148.4 (C), 171.1 (C=O); IR (ATR): $v_{\max } 752,1045,1322,1487,1569,1689,2956 \mathrm{~cm}^{-1}$; UV-VIS (MeOH): $\lambda_{\max } 390 \mathrm{~nm}\left(\varepsilon 30,999 \mathrm{~cm}^{-1} \mathrm{M}^{-1}\right), 300(26,121)$; HRMS $\left(\mathrm{C}_{28} \mathrm{H}_{27} \mathrm{NO}\right)$ calcd m/z $394.2165[\mathrm{M}+\mathrm{H}]^{+}$, obsd $\mathrm{m} / \mathrm{z} 394.2164[\mathrm{M}+\mathrm{H}]^{+}$.

3-Butyl-5-(1,5-di-p-tolylpenta-1,4-diyn-3-ylidene)-1-propyl-1,5-dihydro-2H-pyrrol-2-one (39)

Yellow semi-solid (15\%); ${ }^{1} \mathrm{H}$ NMR $\left(\mathrm{CDCl}_{3}, 400 \mathrm{MHz}\right): \delta 0.95-0.99\left(\mathrm{~m}, 6 \mathrm{H}, \mathrm{CH}_{3}\right)$, 1.40-1.45 (m, 2H, CH $\mathrm{CH}_{2}, 1.60-1.66\left(\mathrm{~m}, 2 \mathrm{H}, \mathrm{CH}_{2}\right), 1.76-1.82\left(\mathrm{~m}, 2 \mathrm{H}, \mathrm{CH}_{2}\right), 2.40\left(\mathrm{~s}, 6 \mathrm{H}, \mathrm{CH}_{3}\right)$, 2.41-2.47 (m, 2H, CH $\mathrm{CH}_{2}, 4.11-4.16\left(\mathrm{~m}, 2 \mathrm{H}, \mathrm{CH}_{2}\right), 7.18-24(\mathrm{~m}, 5 \mathrm{H}, \mathrm{ArH} \& \mathrm{C} 4-\mathrm{H}), 7.33-7.62(\mathrm{~m}$, $4 \mathrm{H}, \mathrm{ArH}) ;{ }^{13} \mathrm{C} \mathrm{NMR}\left(\mathrm{CDCl}_{3}, 100 \mathrm{MHz}\right): \delta 11.2\left(\mathrm{CH}_{3}\right), 13.9\left(\mathrm{CH}_{3}\right), 21.5\left(\mathrm{CH}_{2}\right), 21.6\left(\mathrm{CH}_{2}\right)$, $22.5\left(\mathrm{CH}_{2}\right), 23.4\left(\mathrm{CH}_{2}\right), 25.4\left(\mathrm{CH}_{2}\right), 30.0\left(\mathrm{CH}_{2}\right), 42.2\left(\mathrm{CH}_{2}\right), 85.0(\mathrm{C}), 85.7(\mathrm{C}), 86.9(\mathrm{C}), 92.4$ (C), $96.5(\mathrm{C}), 119.6(\mathrm{C}), 119.8(\mathrm{C}), 129.2(\mathrm{CH}), 129.2(\mathrm{CH}), 129.5(\mathrm{C}), 129.6(\mathrm{C}), 129.7(\mathrm{C}), 131.3$ (CH), $131.5(\mathrm{CH}), 141.4(\mathrm{C}), 147.9(\mathrm{C}), 171.1(\mathrm{C}=\mathrm{O})$; IR (ATR): $v_{\max } 812,1019,1170,1440$, 1507, 1689, $2956 \mathrm{~cm}^{-1}$; UV-VIS (MeOH): $\lambda_{\max } 400 \mathrm{~nm}\left(\varepsilon 25,717 \mathrm{~cm}^{-1} \mathrm{M}^{-1}\right), 300(25,464)$; HRMS $\left(\mathrm{C}_{30} \mathrm{H}_{31} \mathrm{NO}\right)$ calcd m/z $422.2478[\mathrm{M}+\mathrm{H}]^{+}$, obsd m/z $422.2475[\mathrm{M}+\mathrm{H}]^{+}$. 
5-(1,5-Diphenylpenta-1,4-diyn-3-ylidene)-3-hexyl-1-propyl-1,5-dihydro-2H-pyrrol-2-one (40)

Yellow semi-solid (39\%); ${ }^{1} \mathrm{H}$ NMR $\left(\mathrm{CDCl}_{3}, 400 \mathrm{MHz}\right): \delta 0.91-0.98\left(\mathrm{~m}, 6 \mathrm{H}, \mathrm{CH}_{3}\right)$, 1.32-1.42 (m, 6H, CH $), 1.60-1.65\left(\mathrm{~m}, 2 \mathrm{H}, \mathrm{CH}_{2}\right), 1.78-1.83\left(\mathrm{~m}, 2 \mathrm{H}, \mathrm{CH}_{2}\right), 2.41-2.45(\mathrm{~m}, 2 \mathrm{H}$, $\left.\mathrm{CH}_{2}\right), 4.12-4.16\left(\mathrm{~m}, 2 \mathrm{H}, \mathrm{CH}_{2}\right), 7.22(\mathrm{~s}, 1 \mathrm{H}, \mathrm{C} 4-\mathrm{H}), 7.38-7.40(\mathrm{~m}, 6 \mathrm{H}, \mathrm{ArH}), 7.52-7.58(\mathrm{~m}$, $4 \mathrm{H}, \mathrm{ArH}) ;{ }^{13} \mathrm{C} \mathrm{NMR}\left(\mathrm{CDCl}_{3}, 100 \mathrm{MHz}\right): \delta 11.2\left(\mathrm{CH}_{3}\right), 14.1\left(\mathrm{CH}_{3}\right), 22.6\left(\mathrm{CH}_{2}\right), 23.5\left(\mathrm{CH}_{2}\right)$, $25.7\left(\mathrm{CH}_{2}\right), 27.8\left(\mathrm{CH}_{2}\right), 29.1\left(\mathrm{CH}_{2}\right), 31.6\left(\mathrm{CH}_{2}\right), 42.3\left(\mathrm{CH}_{2}\right), 85.5(\mathrm{C}), 86.2(\mathrm{C}), 86.5(\mathrm{C}), 92.2$ (C), $96.2(\mathrm{C}), 122.6(\mathrm{C}), 122.8(\mathrm{C}), 128.4(\mathrm{CH}), 128.5(\mathrm{CH}), 128.7(\mathrm{C}), 129.0(\mathrm{C}), 129.6(\mathrm{C})$, $131.4(\mathrm{CH}), 131.6(\mathrm{CH}), 138.4(\mathrm{C}), 148.4(\mathrm{C}), 171.1(\mathrm{C}=\mathrm{O}) ; \mathrm{IR}(\mathrm{ATR}): v_{\max } 752,1096,1154$, 1441, 1569, 1690, $2925 \mathrm{~cm}^{-}$; UV-VIS (MeOH): $\lambda_{\max } 390 \mathrm{~nm}\left(\varepsilon 34,662 \mathrm{~cm}^{-1} \mathrm{M}^{-1}\right), 300(29,285)$; HRMS $\left(\mathrm{C}_{30} \mathrm{H}_{31} \mathrm{NO}\right)$ calcd $\mathrm{m} / \mathrm{z} 422.2478[\mathrm{M}+\mathrm{H}]^{+}$, obsd m/z $422.2475[\mathrm{M}+\mathrm{H}]^{+}$.

5-(1,5-Diphenylpenta-1,4-diyn-3-ylidene)-3-heptyl-1-propyl-1,5-dihydro-2H-pyrrol-2-one (41)

Yellow semi-solid (96\%); ${ }^{1} \mathrm{H}$ NMR $\left(\mathrm{CDCl}_{3}, 400 \mathrm{MHz}\right): \delta 0.89-0.94\left(\mathrm{~m}, 6 \mathrm{H}, \mathrm{CH}_{3}\right), 1.30$ $1.34\left(\mathrm{~m}, 8 \mathrm{H}, \mathrm{CH}_{2}\right), 1.36-1.42\left(\mathrm{~m}, 2 \mathrm{H}, \mathrm{CH}_{2}\right), 1.59-1.83\left(\mathrm{~m}, 2 \mathrm{H}, \mathrm{CH}_{2}\right), 2.41-2.45\left(\mathrm{~m}, 2 \mathrm{H}, \mathrm{CH}_{2}\right)$, 4.12-4.16 (m, 2H, CH$), 7.22(\mathrm{~s}, 1 \mathrm{H}, \mathrm{C} 4-\mathrm{H}), 7.38-7.40(\mathrm{~m}, 6 \mathrm{H}, \mathrm{ArH}), 7.52-7.57$ (m, 4H, ArH); ${ }^{13} \mathrm{C} \mathrm{NMR}\left(\mathrm{CDCl}_{3}, 100 \mathrm{MHz}\right): \delta 11.2\left(\mathrm{CH}_{3}\right), 14.1\left(\mathrm{CH}_{3}\right), 22.7\left(\mathrm{CH}_{2}\right), 23.4\left(\mathrm{CH}_{2}\right), 25.7\left(\mathrm{CH}_{2}\right)$, $27.9\left(\mathrm{CH}_{2}\right), 29.0\left(\mathrm{CH}_{2}\right), 29.4\left(\mathrm{CH}_{2}\right), 31.7\left(\mathrm{CH}_{2}\right), 42.2\left(\mathrm{CH}_{2}\right), 85.5(\mathrm{C}), 86.2(\mathrm{C}), 86.5(\mathrm{C}), 92.2$ (C), $96.2(\mathrm{C}), 122.6(\mathrm{C}), 122.8(\mathrm{C}), 128.4(\mathrm{CH}), 128.5(\mathrm{CH}), 128.7(\mathrm{C}), 129.0(\mathrm{C}), 129.6(\mathrm{C})$, $131.4(\mathrm{CH}), 131.6(\mathrm{CH}), 138.4(\mathrm{C}), 148.4(\mathrm{C}), 171.1(\mathrm{C}=\mathrm{O}) ; \mathrm{IR}(\mathrm{ATR}): \nu_{\max } 752,1096,1153$, 1322, 1441, 1570, 1693, $2924 \mathrm{~cm}^{-1}$; UV-VIS (MeOH): $\lambda_{\max } 390 \mathrm{~nm}\left(\varepsilon 26,340 \mathrm{~cm}^{-1} \mathrm{M}^{-1}\right), 295$ $(24,641)$; HRMS $\left(\mathrm{C}_{31} \mathrm{H}_{33} \mathrm{NO}\right)$ calcd $\mathrm{m} / \mathrm{z} 436.2635[\mathrm{M}+\mathrm{H}]^{+}$, obsd m/z $436.2633[\mathrm{M}+\mathrm{H}]^{+}$.

5-(1,5-Diphenylpenta-1,4-diyn-3-ylidene)-3-octyl-1-propyl-1,5-dihydro-2H-pyrrol-2-one (42)

Yellow semi-solid (30\%); ${ }^{1} \mathrm{H} \mathrm{NMR}\left(\mathrm{CDCl}_{3}, 400 \mathrm{MHz}\right): \delta 0.92-0.94\left(\mathrm{~m}, 6 \mathrm{H}, \mathrm{CH}_{3}\right)$, 1.30-1.40 (m, 10H, CH $\mathrm{CH}_{2}, 1.60-1.65\left(\mathrm{~m}, 2 \mathrm{H}, \mathrm{CH}_{2}\right), 1.78-1.83\left(\mathrm{~m}, 2 \mathrm{H}, \mathrm{CH}_{2}\right), 2.41-2.45(\mathrm{~m}, 2 \mathrm{H}$, $\left.\mathrm{CH}_{2}\right), 4.12-4.16\left(\mathrm{~m}, 2 \mathrm{H}, \mathrm{CH}_{2}\right), 7.22(\mathrm{~s}, 1 \mathrm{H}, \mathrm{C} 4-\mathrm{H}), 7.38-7.40(\mathrm{~m}, 6 \mathrm{H}, \mathrm{ArH}), 7.52-7.57(\mathrm{~m}$, $4 \mathrm{H}, \mathrm{ArH}) ;{ }^{13} \mathrm{C} \mathrm{NMR}\left(\mathrm{CDCl}_{3}, 100 \mathrm{MHz}\right): \delta 11.2\left(\mathrm{CH}_{3}\right), 14.1\left(\mathrm{CH}_{3}\right), 22.7\left(\mathrm{CH}_{2}\right), 23.5\left(\mathrm{CH}_{2}\right)$, $25.7\left(\mathrm{CH}_{2}\right), 27.9\left(\mathrm{CH}_{2}\right), 29.2\left(\mathrm{CH}_{2}\right), 29.3\left(\mathrm{CH}_{2}\right), 29.4\left(\mathrm{CH}_{2}\right), 31.8\left(\mathrm{CH}_{2}\right), 42.2\left(\mathrm{CH}_{2}\right), 85.5$ (C), $86.2(\mathrm{C}), 86.5(\mathrm{C}), 92.2(\mathrm{C}), 96.2(\mathrm{C}), 122.6(\mathrm{C}), 122.8(\mathrm{C}), 128.4(\mathrm{CH}), 128.5(\mathrm{CH}), 128.7$ (C), $129.0(\mathrm{C}), 129.6(\mathrm{C}), 131.4(\mathrm{CH}), 131.6(\mathrm{CH}), 138.4(\mathrm{C}), 148.4(\mathrm{C}), 171.1(\mathrm{C}=\mathrm{O})$; IR (ATR): $V_{\max }$ 752, 1096, 1322, 1440, 1570, 1692, $2923 \mathrm{~cm}^{-1}$; UV-VIS (MeOH): $\lambda_{\max } 395 \mathrm{~nm}(\varepsilon$ 47,392 $\left.\mathrm{cm}^{-1} \mathrm{M}^{-1}\right), 300(38,669)$; HRMS $\left(\mathrm{C}_{32} \mathrm{H}_{35} \mathrm{NO}\right)$ calcd $\mathrm{m} / \mathrm{z} 450.2791[\mathrm{M}+\mathrm{H}]^{+}$, obsd m/z $450.2788[\mathrm{M}+\mathrm{H}]^{+}$.

1,3-Dibutyl-5-(1,5-diphenylpenta-1,4-diyn-3-ylidene)-1,5-dihydro-2H-pyrrol-2-one (43)

Yellow semi-solid (78\%); ${ }^{1} \mathrm{H} \mathrm{NMR}\left(\mathrm{CDCl}_{3}, 400 \mathrm{MHz}\right): \delta 0.90-0.99\left(\mathrm{~m}, 6 \mathrm{H}, \mathrm{CH}_{3}\right)$, 1.28-1.48 (m, 4H, $\left.\mathrm{CH}_{2}\right), 1.56-1.66\left(\mathrm{~m}, 2 \mathrm{H}, \mathrm{CH}_{2}\right), 1.71-1.79\left(\mathrm{~m}, 2 \mathrm{H}, \mathrm{CH}_{2}\right), 2.40-2.46(\mathrm{~m}, 2 \mathrm{H}$, $\left.\mathrm{CH}_{2}\right), 4.15-4.19\left(\mathrm{~m}, 2 \mathrm{H}, \mathrm{CH}_{2}\right), 7.22(\mathrm{~m}, 1 \mathrm{H}, \mathrm{C} 4-\mathrm{H}), 7.36-7.40(\mathrm{~m}, 6 \mathrm{H}, \mathrm{ArH}), 7.51-7.58(\mathrm{~m}$, $4 \mathrm{H}, \mathrm{ArH}) ;{ }^{13} \mathrm{C} \mathrm{NMR}\left(\mathrm{CDCl}_{3}, 100 \mathrm{MHz}\right): \delta 13.8\left(\mathrm{CH}_{3}\right), 13.9\left(\mathrm{CH}_{3}\right), 20.0\left(\mathrm{CH}_{2}\right), 22.5\left(\mathrm{CH}_{2}\right)$, $22.4\left(\mathrm{CH}_{2}\right), 29.9\left(\mathrm{CH}_{2}\right), 32.4\left(\mathrm{CH}_{2}\right), 40.6\left(\mathrm{CH}_{2}\right), 85.5(\mathrm{C}), 86.2(\mathrm{C}), 86.5(\mathrm{C}), 92.2(\mathrm{C}), 96.2(\mathrm{C})$, $122.6(\mathrm{C}), 122.8(\mathrm{C}), 128.4(\mathrm{CH}), 128.5(\mathrm{CH}), 128.7(\mathrm{C}), 129.0(\mathrm{C}), 129.7(\mathrm{C}), 131.4(\mathrm{CH}), 131.6$ (CH), $138.3(\mathrm{C}), 148.4(\mathrm{C}), 171.1(\mathrm{C}=\mathrm{O})$; IR (ATR): $v_{\max } 751,801,1096,1154,1437,1487,1570$, 1689, $2925 \mathrm{~cm}^{-1}$; UV-VIS (MeOH): $\lambda_{\max } 385 \mathrm{~nm}\left(\varepsilon 26,773 \mathrm{~cm}^{-1} \mathrm{M}^{-1}\right), 300(25,306)$; HRMS $\left(\mathrm{C}_{29} \mathrm{H}_{29} \mathrm{NO}\right)$ calcd $\mathrm{m} / \mathrm{z} 408.2322[\mathrm{M}+\mathrm{H}]^{+}$, obsd m/z $408.2323[\mathrm{M}+\mathrm{H}]^{+}$.

3-Butyl-5-(penta-1,4-diyn-3-ylidene)-1-propyl-1,5-dihydro-2H-pyrrol-2-one (44)

Yellow semi-solid (31\%); ${ }^{1} \mathrm{H} \mathrm{NMR}\left(\mathrm{CDCl}_{3}, 400 \mathrm{MHz}\right): \delta 0.86-0.95\left(\mathrm{~m}, 6 \mathrm{H}, \mathrm{CH}_{3}\right)$, 1.35-1.40 (m, 2H, CH 2$), 1.52-1.68\left(\mathrm{~m}, 4 \mathrm{H}, \mathrm{CH}_{2}\right), 2.35-2.39\left(\mathrm{~m}, 2 \mathrm{H}, \mathrm{CH}_{2}\right), 3.21(\mathrm{~s}, 1 \mathrm{H}), 3.41$ (s, $1 \mathrm{H}), 3.93-3.97\left(\mathrm{~m}, 2 \mathrm{H}, \mathrm{CH}_{2}\right), 7.07(\mathrm{~s}, 1 \mathrm{H}, \mathrm{C} 4-\mathrm{H}) ;{ }^{13} \mathrm{C} \mathrm{NMR}\left(\mathrm{CDCl}_{3}, 100 \mathrm{MHz}\right): \delta 10.6\left(\mathrm{CH}_{3}\right)$, $13.8\left(\mathrm{CH}_{3}\right), 22.4\left(\mathrm{CH}_{2}\right), 23.3\left(\mathrm{CH}_{2}\right), 25.2\left(\mathrm{CH}_{2}\right), 29.7\left(\mathrm{CH}_{2}\right), 41.9\left(\mathrm{CH}_{2}\right), 79.0(\mathrm{C}), 79.9(\mathrm{C})$, $80.4(\mathrm{C}), 83.2(\mathrm{C}), 84.4(\mathrm{C}), 129.6(\mathrm{CH}), 139.2(\mathrm{C}), 151.2(\mathrm{C}), 170.9(\mathrm{C}=\mathrm{O})$; IR (ATR): $v_{\max } 696$, 855, 1018, 1169, 1364, 1377, 1457, 1694, 2930, $2959 \mathrm{~cm}^{-1}$; UV-VIS (MeOH): $\lambda_{\max } 305 \mathrm{~nm}$ ( $\left.2558 \mathrm{~cm}^{-1} \mathrm{M}^{-1}\right)$; HRMS $\left(\mathrm{C}_{16} \mathrm{H}_{19} \mathrm{NO}\right)$ calcd m/z $242.1539[\mathrm{M}+\mathrm{H}]^{+}$, obsd m/z 242.1540 $[\mathrm{M}+\mathrm{H}]^{+}$.

\section{Conclusions}

Fifteen novel alkyne analogues of DHPs with various substitution patterns and aliphatic chain lengths were successfully synthesized via lactamisation and Sonogashira 
coupling reactions in moderate to high yields. The Sonogashira reaction was carried out with DHPs and alkynes in the presence of $\mathrm{CuI}$, palladium catalyst $\mathrm{PdCl}_{2}\left(\mathrm{PPh}_{3}\right)_{2}$, and TEA. Biological testing demonstrated that several compounds showed moderate activity against the P. aeruginosa MH602 reporter strain with little bactericidal effect. The present study represents the first application of the Sonogashira reaction to DHP scaffolds for the synthesis of novel bacterial QS inhibitors.

Supplementary Materials: The following are available online at https: / www.mdpi.com/article / 10.3390/antibiotics11020151/s1: Table S1: X-ray Experimental details for compound 18, Table S2: X-ray Experimental details for compound 26, Table S3: Selected geometric parameters, Table S4: Selected hydrogen-bond parameters, File S1: NMR spectra for ${ }^{1} \mathrm{H}$ NMR and ${ }^{13} \mathrm{C}$ NMR.

Author Contributions: Conceptualization, B.A., G.I. and N.K.; methodology, B.A., T.T.Y. and S.S.; resources, N.K. and D.S.B.; X-ray data and analysis, B.A. and M.B.; writing-original draft preparation, B.A. and T.T.Y.; writing - review and editing, B.A. and T.T.Y.; supervision, N.K. and D.S.B.; funding acquisition, B.A., N.K. and D.S.B. All authors have read and agreed to the published version of the manuscript.

Funding: This work was supported by a Linkage Project grant (LP150100752) and a Discovery Project grant (DP180100845) from the Australian Research Council.

Data Availability Statement: Data is contained within the article and Supplementary Materials.

Acknowledgments: We thank the NMR and Bioanalytical Mass Spectrometry Facility (BMSF) facilities at UNSW. The authors would like to acknowledge the Saudi Ministry of Education and King Khalid University for an Endowment Fund and financial support given to B. Almohaywi.

Conflicts of Interest: The authors declare no conflict of interest.

\section{References}

1. Welsh, M.A.; Blackwell, H.E. Chemical probes of quorum sensing: From compound development to biological discovery. FEMS Microbiol. Rev. 2016, 40, 774-794. [CrossRef] [PubMed]

2. Blair, J.M.; Webber, M.A.; Baylay, A.J.; Ogbolu, D.O.; Piddock, L.J. Molecular mechanisms of antibiotic resistance. Nat. Rev. Microbiol. 2015, 13, 42-51. [CrossRef] [PubMed]

3. Fuqua, C.; Greenberg, E.P. Listening in on bacteria: Acyl-homoserine lactone signalling. Nat. Rev. Mol. Cell Biol. $2002,3,685-695$. [CrossRef] [PubMed]

4. Manny, A.J.; Kjelleberg, S.; Kumar, N.; de Nys, R.; Read, R.W.; Steinberg, P. Reinvestigation of the sulfuric acid-catalysed cyclisation of brominated 2-alkyllevulinic acids to 3-alkyl-5-methylene-2 (5H)-furanones. Tetrahedron 1997, 53, 15813-15826. [CrossRef]

5. Hentzer, M.; Riedel, K.; Rasmussen, T.B.; Heydorn, A.; Andersen, J.B.; Parsek, M.R.; Rice, S.A.; Eberl, L.; Molin, S.; Høiby, N. Inhibition of quorum sensing in Pseudomonas aeruginosa biofilm bacteria by a halogenated furanone compound. Microbiology 2002, 148, 87-102. [CrossRef]

6. Hentzer, M.; Wu, H.; Andersen, J.B.; Riedel, K.; Rasmussen, T.B.; Bagge, N.; Kumar, N.; Schembri, M.A.; Song, Z.; Kristoffersen, P. Attenuation of Pseudomonas aeruginosa virulence by quorum sensing inhibitors. EMBO J. 2003, 22, 3803-3815. [CrossRef]

7. Kutty, S.K.; Barraud, N.; Pham, A.; Iskander, G.; Rice, S.A.; Black, D.S.; Kumar, N. Design, synthesis, and evaluation of fimbrolide-nitric oxide donor hybrids as antimicrobial agents. J. Med. Chem. 2013, 56, 9517-9529. [CrossRef]

8. Wagner, S.; Sommer, R.; Hinsberger, S.; Lu, C.; Hartmann, R.W.; Empting, M.; Titz, A. Novel strategies for the treatment of Pseudomonas aeruginosa infections. J. Med. Chem. 2016, 59, 5929-5969. [CrossRef]

9. Li, W.-R.; Lin, S.T.; Hsu, N.-M.; Chern, M.-S. Efficient total synthesis of pulchellalactam, a CD45 protein tyrosine phosphatase inhibitor. J. Org. Chem. 2002, 67, 4702-4706. [CrossRef]

10. Mase, N.; Nishi, T.; Takamori, Y.; Yoda, H.; Takabe, K. First synthesis of (R)-(-)-5-hydroxy-3-methyl-3-pyrrolin-2-one (jatropham) by lipase-catalyzed kinetic resolution. Tetrahedron Asymmetry 1999, 10, 4469-4471. [CrossRef]

11. Yates, E.A.; Philipp, B.; Buckley, C.; Atkinson, S.; Chhabra, S.R.; Sockett, R.E.; Goldner, M.; Dessaux, Y.; Cámara, M.; Smith, H. $\mathrm{N}$-acylhomoserine lactones undergo lactonolysis in a $\mathrm{pH}-$, temperature-, and acyl chain length-dependent manner during growth of Yersinia pseudotuberculosis and Pseudomonas aeruginosa. Infect. Immun. 2002, 70, 5635-5646. [CrossRef] [PubMed]

12. Byers, J.T.; Lucas, C.; Salmond, G.P.; Welch, M. Nonenzymatic turnover of an Erwinia carotovora quorum-sensing signaling molecule. J. Bacteriol. 2002, 184, 1163-1171. [CrossRef] [PubMed]

13. Lyons, T.; Gahan, C.G.; O'Sullivan, T.P. Structure-activity relationships of furanones, dihydropyrrolones and thiophenones as potential quorum sensing inhibitors. Future Med. Chem. 2020, 12, 1925-1943. [CrossRef] [PubMed] 
14. Almohaywi, B.; Taunk, A.; Wenholz, D.S.; Nizalapur, S.; Biswas, N.N.; Ho, K.K.; Rice, S.A.; Iskander, G.; Black, D.S.; Griffith, R. Design and synthesis of lactams derived from mucochloric and mucobromic acids as Pseudomonas aeruginosa quorum sensing inhibitors. Molecules 2018, 23, 1106. [CrossRef] [PubMed]

15. Almohaywi, B.; Yu, T.T.; Iskander, G.; Chan, D.S.; Ho, K.K.; Rice, S.; Black, D.S.; Griffith, R.; Kumar, N. Dihydropyrrolones as bacterial quorum sensing inhibitors. Bioorg. Med. Chem. Lett. 2019, 29, 1054-1059. [CrossRef] [PubMed]

16. Goh, W.-K.; Gardner, C.R.; Sekhar, K.V.C.; Biswas, N.N.; Nizalapur, S.; Rice, S.A.; Willcox, M.; Black, D.S.; Kumar, N. Synthesis, quorum sensing inhibition and docking studies of 1, 5-dihydropyrrol-2-ones. Bioorg. Med. Chem. 2015, 23, 7366-7377. [CrossRef]

17. Sabir, S.; Suresh, D.; Subramoni, S.; Das, T.; Bhadbhade, M.; Black, D.S.; Rice, S.A.; Kumar, N. Thioether-linked dihydropyrrol-2one analogues as PqsR antagonists against antibiotic resistant Pseudomonas aeruginosa. Bioorg. Med. Chem. 2021, 31 , 115967. [CrossRef]

18. Sabir, S.; Yu, T.T.; Kuppusamy, R.; Almohaywi, B.; Iskander, G.; Das, T.; Willcox, M.D.; Black, D.S.; Kumar, N. Novel Seleno-and Thio-urea-Containing Dihydropyrrol-2-one Analogues as Antibacterial Agents. Antibiotics 2021, 10, 321. [CrossRef]

19. Ahmad, A.; Husain, A.; Khan, S.A.; Mujeeb, M.; Bhandari, A. Design, synthesis, molecular properties and antimicrobial activities of some novel $2(3 \mathrm{H})$ pyrrolone derivatives. J. Saudi Chem. Soc. 2015, 19, 340-346. [CrossRef]

20. Husain, A.; Alam, M.M.; Shaharyar, M.; Lal, S. Antimicrobial activities of some synthetic butenolides and their pyrrolone derivatives. J. Enzym. Inhib. Med. Chem. 2010, 25, 54-61. [CrossRef]

21. Abdelbaset, M.S.; Abdel-Aziz, M.; Abuo-Rahma, G.E.-D.A.; Ramadan, M.; Abdelrahman, M.H. Pyridazinones and pyrrolones as promising Scaffolds in Medicinal Chemistry. J. Adv. Biomed. Pharm. Sci. 2019, 2, 19-28. [CrossRef]

22. Koz'minykh, V.; Igidov, N.; Zykova, S.; Kolla, V.; Shuklina, N.; Odegova, T. Synthesis and pharmacological activity of 3-hydroxy-1, 5-diaryl-4-pivaloyl-2, 5-dihydro-2-pyrrolones. Pharm. Chem. J. 2002, 36, 188-191. [CrossRef]

23. Miranda, A.C.; Barbosa, L.C.; Masood, M.A.; Varejao, J.O.; Sordi, M.; Benfatti, C.S.A.; Pimenta, A.L. Inhibitory Effect on Biofilm Formation of Pathogenic Bacteria Induced by Rubrolide Lactam Analogues. ACS Omega 2018, 3, 18475-18480. [CrossRef]

24. Pereira, U.; Moreira, T.; Barbosa, L.; Maltha, C.; Bomfim, I.; Maranhão, S.; Moraes, M.; Pessoa, C.; Barros-Nepomuceno, F Rubrolide analogues and their derived lactams as potential anticancer agents. MedChemComm 2016, 7, 345-352. [CrossRef]

25. Pereira, U.A.; Barbosa, L.C.; Demuner, A.J.; Silva, A.A.; Bertazzini, M.; Forlani, G. Rubrolides as model for the development of new lactones and their aza analogs as potential photosynthesis inhibitors. Chem. Biodivers. 2015, 12, 987-1006. [CrossRef]

26. Liu, Z.; Zhang, P.; Qin, Y.; Zhang, N.; Teng, Y.; Venter, H.; Ma, S. Design and synthesis of aryl-substituted pyrrolidone derivatives as quorum sensing inhibitors. Bioorg. Chem. 2020, 105, 104376. [CrossRef]

27. Maretina, I.A.; Trofimov, B.A. Enediyne antibiotics and their models: New potential of acetylene chemistry. Russ. Chem. Rev. 2006, 75, 825-845. [CrossRef]

28. Minto, R.E.; Blacklock, B.J. Biosynthesis and function of polyacetylenes and allied natural products. Prog. Lipid Res. 2008, 47, 233-306. [CrossRef]

29. Voronin, V.V.; Ledovskaya, M.S.; Bogachenkov, A.S.; Rodygin, K.S.; Ananikov, V.P. Acetylene in organic synthesis: Recent progress and new uses. Molecules 2018, 23, 2442. [CrossRef]

30. Wermuth, C.G. The Practice of Medicinal Chemistry; Academic Press: Cambridge, MA, USA, 2015; pp. 319-357.

31. Boukouvalas, J.; Côté, S.; Ndzi, B. Facile access to 4-(1-alkynyl)-2 (5H)-furanones by Sonogashira coupling of terminal acetylenes with $\beta$-tetronic acid bromide: Efficient synthesis of cleviolide. Tetrahedron Lett. 2007, 48, 105-107. [CrossRef]

32. Sonogashira, K.; Tohda, Y.; Hagihara, N. A convenient synthesis of acetylenes: Catalytic substitutions of acetylenic hydrogen with bromoalkenes, iodoarenes and bromopyridines. Tetrahedron Lett. 1975, 16, 4467-4470. [CrossRef]

33. Bellina, F.; Falchi, E.; Rossi, R. Regioselective synthesis of cytotoxic 4-(1-alkynyl)-substituted 2-(5H)-furanones. Tetrahedron 2003, 59, 9091-9100. [CrossRef]

34. Bonacorso, H.G.; Rodrigues, M.B.; Feitosa, S.C.; Coelho, H.S.; Alves, S.H.; Keller, J.T.; Rosa, W.C.; Ketzer, A.; Frizzo, C.P.; Martins, M.A. Synthesis and antimicrobial screening of 2-alkyl (aryl)-7-chloro-6-fluoro-4-(trifluoromethyl)-quinolines and their phenylacetylene derivatives, promoted by Sonogashira cross-coupling reaction. J. Fluor. Chem. 2018, 205, 49-57. [CrossRef]

35. Richards, J.J.; Melander, C. Synthesis of a 2-aminoimidazole library for antibiofilm screening utilizing the Sonogashira reaction. J. Org. Chem. 2008, 73, 5191-5193. [CrossRef]

36. Wang, D.; Gao, S. Sonogashira coupling in natural product synthesis. Org. Chem. Front. 2014, 1, 556-566. [CrossRef]

37. Biswas, N.N.; Iskander, G.M.; Mielczarek, M.; Yu, T.T.; Black, D.S.; Kumar, N. Alkyne-substituted fimbrolide analogues as novel bacterial quorum-sensing inhibitors. Aust. J. Chem. 2018, 71, 708-715. [CrossRef]

38. Goh, W.K.; Iskander, G.; Black, D.S.; Kumar, N. An efficient lactamization of fimbrolides to novel 1, 5-dihydropyrrol-2-ones. Tetrahedron Lett. 2007, 48, 2287-2290. [CrossRef]

39. Chinchilla, R.; Nájera, C. The Sonogashira reaction: A booming methodology in synthetic organic chemistry. Chem. Rev. 2007, 107, 874-922. [CrossRef]

40. Almohaywi, B.; Iskander, G.; Black, D.; Kumar, N. Antimicrobial Discovery, Development, Stewardship and Susceptibility Testing. In Proceedings of the 1st International Electronic Conference on Antibiotics-The Equal Power of Antibiotics and Antimicrobial Resistance, Online, 8-17 May 2021; Volume 68.

41. Almohaywi, B.; Iskander, G.; Yu, T.T.; Bhadbhade, M.; Black, D.S.; Kumar, N. Copper-mediated Chan-Evans-Lam N-arylation of 5-methylene-4-aryl-1, 5-dihydro-2H-pyrrol-2-one derivatives. Tetrahedron Lett. 2018, 59, 811-814. [CrossRef] 
42. Biswas, N.N.; Kutty, S.K.; Iskander, G.M.; Mielczarek, M.; Bhadbhade, M.M.; Gardner, C.R.; Black, D.S.; Kumar, N. Synthesis of brominated novel N-heterocycles: New scaffolds for antimicrobial discovery. Tetrahedron 2016, 72, 539-546. [CrossRef]

43. Kutty, S.K. Novel Nitric Oxide Donors as Antimicrobial Agents. Ph.D. Thesis, University of New South Wales, Sydney, Australia, 2012.

44. Bruker. APEX3, SAINT-Plus and SADABS; Bruker AXS Inc.: Madison, WI, USA, 2016.

45. Sheldrick, G.M. SHELXT-Integrated space-group and crystal-structure determination. Acta Crystallogr. Sect. A 2015, 71, 3-8. [CrossRef] [PubMed]

46. Sheldrick, G.M. Crystal structure refinement with SHELXL. Acta Crystallogr. Sect. C Struct. Chem. 2015, 71, 3-8. [CrossRef] [PubMed]

47. Dolomanov, O.V.; Bourhis, L.J.; Gildea, R.J.; Howard, J.A.; Puschmann, H. OLEX2: A complete structure solution, refinement and analysis program. J. Appl. Crystallogr. 2009, 42, 339-341. [CrossRef] 